In cooperation with Oakland County, Michigan

\title{
Effects of Urban Land-Use Change on Streamflow and Water Quality in Oakland County, Michigan, 1970-2003, as Inferred from Urban Gradient and Temporal Analysis
}

Scientific Investigations Report 2005-5016 


\section{Effects of Urban Land-Use Change on Streamflow and Water Quality in Oakland County, Michigan, 1970-2003, as Inferred from Urban Gradient and Temporal Analysis}

By Stephen S. Aichele

In cooperation with Oakland County, Michigan

Scientific Investigations Report 2005-5016 


\section{U.S. Department of the Interior \\ Gale A. Norton, Secretary \\ U.S. Geological Survey \\ Charles G. Groat, Director}

U.S. Geological Survey, Reston, Virginia: 2005

For sale by U.S. Geological Survey, Information Services
Box 25286, Denver Federal Center
Denver, CO 80225
For more information about the USGS and its products:
Telephone: 1-888-ASK-USGS
World Wide Web: http://www.usgs.gov/

Any use of trade, product, or firm names in this publication is for descriptive purposes only and does not imply endorsement by the U.S. Government.

Although this report is in the public domain, permission must be secured from the individual copyright owners to reproduce any copyrighted materials contained within this report.

Suggested citation:

Aichele, Stephen, 2005, Effects of Urban Land-Use Change on Streamflow and Water Quality in Oakland County, Michigan, 1970-2003, as Inferred from Urban Gradient and Temporal Analysis: U.S. Geological Survey Scientific Investigations Report 2005-5016, 22p. 


\section{Contents}

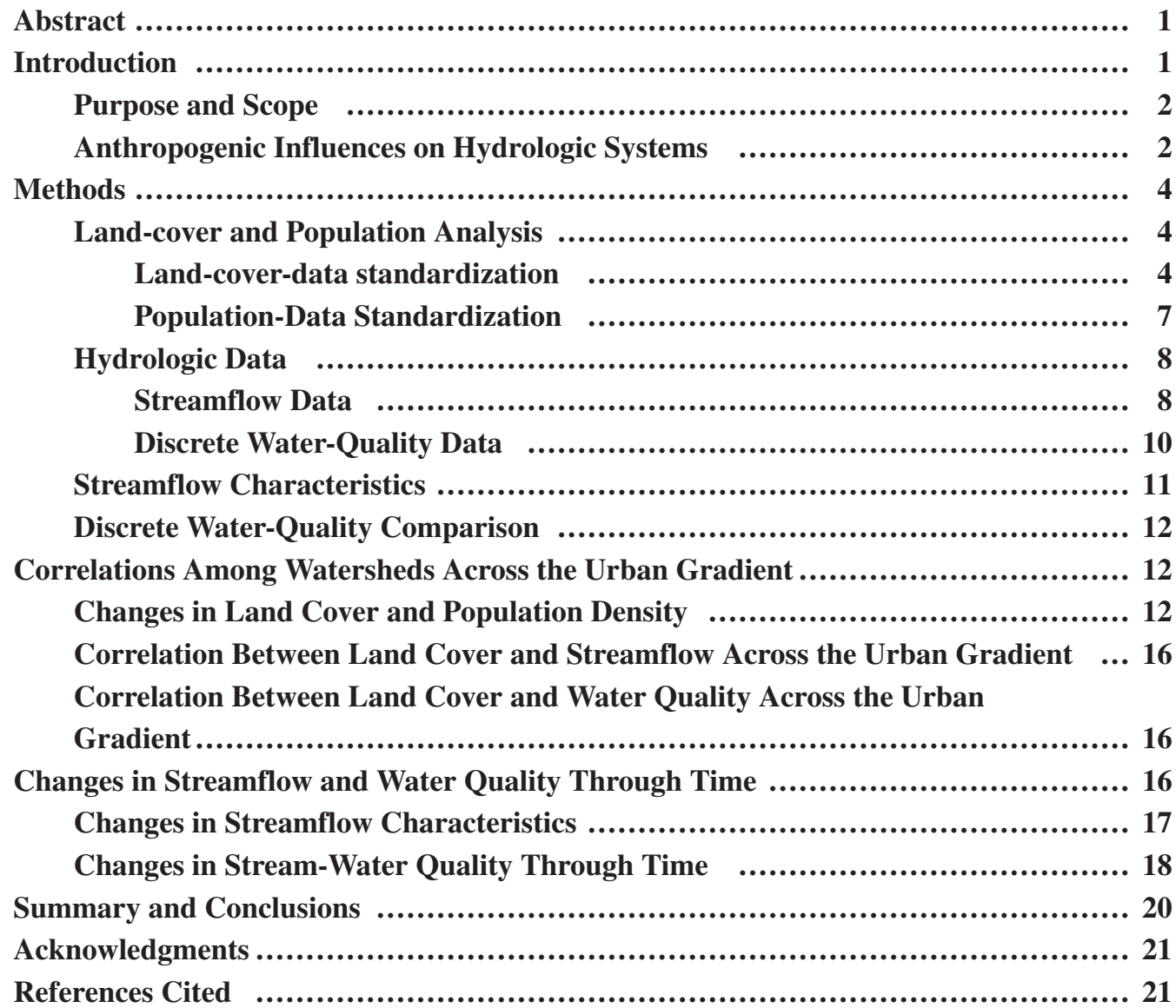

\section{List of Figures}

1. Conversion of land to urban covers in Oakland County, Mich, between 1980 and 2000 .

2. Maps showing land-use/land-cover change in Oakland County, Mich, 1980-2000

3. Graph showing relative landscape representation for selected land covers at various cell sizes ............................................................ 6

4. Locations of discrete water-quality sample sites, continuous streamflowgaging stations, and specific conductance monitors

5. Comparison of geometric mean (a.) specific conductance, (b.) chloride concentration, (c.)phosphorous concentration, (d.) sulfate concentration, (e.) nitrate concentration, and (f.) noncarbonated hardness of discrete water-quality samples collected during low flow conditions, 1966-1970 and 2001-2003 


\section{List of Tables}

1. Relative percent landscape representation for selected land covers at various cell sizes

2. Fitted population-density coefficients by year for each residential land-use/land-cover class in southeast Michigan

3. Identification and period of record for streamflow-gaging stations used in this study

4. Sites where discrete water-quality samples were collected during 2001-2003

5. Water-quality characteristics and analytical methods for inorganic stream-water-quality samples collected in Oakland County, Michigan, during 2001, 2002, and 2003 ....

6. Land-use/land-cover composition of monitored watersheds in Oakland County, Michigan, 1980 to 2000

7. Estimated population densities in gaged watersheds in Oakland County, Michigan, 1980 to 2000.

8. Spearman Rho values correlating specific characteristics of daily streamflow to land-cover and urbanization metrics across an urban gradient

9. Spearman rank order correlations between water-quality parameters and land-use/land-cover metrics

10. Spearman rank-order correlations between year and selected annual daily-streamflow statistics for the water years 1970 through 2003

\section{Conversion Factors and Datum}

Inch/Pound to SI

\begin{tabular}{|c|c|c|}
\hline Multiply & By & To obtain \\
\hline \multicolumn{3}{|c|}{ Length } \\
\hline foot $(\mathrm{ft})$ & 0.3048 & meter $(m)$ \\
\hline \multicolumn{3}{|c|}{ Area } \\
\hline acre & 4,047 & square meter (m2) \\
\hline acre & 0.004047 & square kilometer (km2) \\
\hline square mile (sq. mi.) & 2.590 & square kilometer $(\mathrm{km} 2)$ \\
\hline \multicolumn{3}{|c|}{ Flow rate } \\
\hline million gallons per day (Mgal/d) & 3,785 & cubic meter per day $(\mathrm{m} 3 / \mathrm{d})$ \\
\hline
\end{tabular}

Horizontal coordinate information is referenced to the North American Datum of 1983 (NAD 83).

Water year, as used in this report, refers to the period from October 1 to September 30. For example, water year 2004 begins October 1, 2003, and ends September 30, 2004. 


\title{
Effects of urban land-use change on streamflow and water quality in Oakland County, Michigan, 1970-2003, as inferred from urban gradient and temporal analysis
}

\author{
By Stephen S. Aichele
}

\section{Abstract}

Various adverse hydrologic effects on streams have been attributed to urban development and expanded impervious surface area, including increased high flows, decreased low flows, increased variability (commonly referred to as flashiness), nutrient enrichment, and increased dissolved solids concentrations. These effects are often observed through the use of urban-gradient studies, which compare hydrologic characteristics among watersheds with different levels of development. This technique is frequently applied when comparable prior data are not available for the watersheds of interest.

During 1966 - 1970, and again during 2001 - 2003, the U.S. Geological Survey collected a series of lowflow water-chemistry samples. Streamflow-gaging stations were operated throughout the period from 19662003 as part of ongoing monitoring operations. This study compares these two water-quality data sets; tests the streamflow data for trends in high flows, low flows, and flashiness; and correlates 2000 land use with waterquality and streamflow data collected during the 2001 - 2003 study.

Despite substantial change in land use during 1980 - 2000, with urban land covers replacing open space, forest, and agriculture, little evidence is found in the time-series data of alteration of the daily streamflow characteristics or nutrient enrichment in the study watersheds. However, a distinct shift is observable in chloride concentrations. Strong positive correlations exist across the urban gradient between development and increased peak flows as well as between development and increased flashiness. Correlations of water-quality data to development metrics show strong positive correlations with increased dissolved solids and salt content, as well as increased concentrations of fecal indicator bacteria (Eschericia coli).

This apparent contradiction may be caused by the differences in the changes measured in each analysis. The change-through-time approach describes change from a fixed starting point of approximately 1970; the gradient approach describes the cumulative effect of all change up to approximately 2000. These findings indicate that although urbanization in Oakland County results in most of the effects observed in the literature, as evidenced in the gradient approach, relatively few of the anticipated effects have been observed during the past three decades. This relative stability despite rapid land-cover change may be related to efforts to mitigate the effects of development and a general decrease in the density of new residential development. It may also be related to external factors such as climate variability and reduced atmospheric deposition of specific chemicals.

\section{Introduction}

Land-cover change - and more specifically the rate of land-cover change - has been identified as a serious issue in Michigan (Michigan Land Use Leadership Council, 2003) and elsewhere in the United States. Societal changes, such as those in the transportation infrastructure and the economy, have made the centralization of services and activities associated with cities less necessary, resulting in more dispersed settlement (Garreau, 1992). The postulated effects of land-cover change are widespread, ranging from destruction of habitat (Malmqvist and Rundle, 2002) to alteration of climate (Kalnai and Cal, 2003). In addition, land-cover change has been clearly documented to have a significant 
influence on hydrologic systems (Leopold, 1968).

These effects are of particular interest in areas undergoing rapid urban expansion, such as Oakland County, Michigan, which includes 910 square miles within the Detroit metropolitan area (figure 1). Oakland County also provides a rare opportunity to study these effects over a long term, because a comprehensive water resources assessment was completed in 1972 (Twenter and Knutilla, 1972), and because of the large number of continuously operated streamflow-gaging stations in the county.

\section{Purpose and Scope}

This report describes the streamflow and waterquality effects of land-use change in 14 watersheds in Oakland County, Mich., by making comparisons to historical data and by correlating hydrologic characteristics to land use across an urban gradient. Urban gradient studies compare hydrologic characteristics among watersheds with different levels of development, a technique frequently applied when comparable prior data are not available for the watersheds of interest. A process is described to standardize disparate land-cover source datasets to consistent measures of land cover and population density in watersheds through time. The resulting standardized land-cover data are then compared to several metrics of streamflow and water quality intended to describe both change through time in specific watersheds and concurrent effects across watersheds. These metrics include the 1- and 99-percent-exceedance flows, streamflow variability, and discretely measured water-quality characteristics.

\section{Anthropogenic Influences on Hydrologic Systems}

The effects of urbanization on hydrologic systems have been a concern in America for more than 200 years. Benjamin Franklin, writing in his will, expressed concern that the tendency to cover land with buildings and pavements would have detrimental impacts on the quantity and quality of water available in the wells then serving the City of Philadelphia (Smyth, 1907). Today our concerns are much the same, only projected from within city boundaries to the outlying suburban areas.

In response to the development boom during the period following World War II, numerous authors addressed the issue of urbanization in the 1960s. A series of USGS Water-Supply Papers (WSP 1591A - E) described the then-current state of the science regarding influences of urbanization and land-cover change on water supply, water quality, flood inundation, and sediment transport, as well as difficulties in modeling the engineered urban hydrology systems. This group of studies all relied on temporal analysis methods to evaluate hydrologic trends in specific watersheds.

Savini and Kammerer (1961) published an overview of interactions between urbanization and water resources. The focus was on providing safe drinkingwater supplies for communities and sufficient water flows to meet other uses, such as irrigation and waste disposal, without impairing water quality. A study of Permanente Creek in California (Harris and Rantz, 1964) yielded clear evidence of increased runoff as a result of urbanization through the analysis of streamflow records and aerial photography. An increase in impervious surface from 4 percent to 19 percent of watershed area resulted in a 44-percent increase in peak flows. Studies of flood-frequency characteristics in seven basins surrounding Charlotte, N. C. (Martens, 1968) documented the increased flood potential associated with increased impervious surfaces. Finally, study of streamflow and sediment transport in a developing watershed in northern Virginia (Vice and others, 1969) identified sediment loads between 10 and 2,000 times greater than with undeveloped land covers.

In 1968, Luna Leopold summarized much of this research in his "Hydrology for Urban Planning - A Guidebook on the Hydrologic Effects of Urban Land Use" (Leopold, 1968). These foundational studies, however, focus largely on the development model employed from 1945-1970 - relatively small properties with large fractions of the property in impervious surface, as well as curbs, sidewalks, storm drains, and sewers. Runoff control structures, now required, were rare, as were the larger-lot rural residences that have become increasingly common in recent decades.

Subsequent research in this area has largely added supplemental evidence and detail to the processes proposed in these studies. Owe (1985) identified alteration in the long-term water budget of the Chester Creek watershed in Pennsylvania as a result of suburban development by looking at cumulative development metrics, as opposed to change. McMahon and others (2003), who studied more recently developed areas, suggested that the effects of urbanization may be ameliorated to some degree by fragmentation of developed areas. In other words, one large developed area may have a larger effect than many small developed areas with the same total area. This finding may indicate a shift in the way land cover relates to hydrology, based on change in landdevelopment patterns and practices. Choi and others (2003) identified a relation between the annual rainfall and the flow volumes in urbanizing watersheds.

The effects of urbanization on water chemistry are not as certain. Tufford and others (2003) observed higher dissolved organic nitrogen and ammonia concentrations in forested watersheds than in urban watersheds, whereas nitrate and total phosphorus were higher in urban watersheds. However, Tufford and others (2003) 
were unable to develop significant statistical relations between land cover and nutrient concentrations in their study streams. Im and others (2003) evaluated various development scenarios in the Polecat Creek watershed of Virginia. This study indicated that although runoff volumes would increase, phosphorus and nitrogen concentrations would generally decrease because of decreased agricultural land. Nitrate, specifically, is projected to increase because of use of lawn fertilizers.

Several recent studies have investigated the effects of urbanization in fecal indicator bacteria. Smith and others (2001) identified strong correlations between urban land covers and water-quality impairment as indicated by fecal coliforms. Frenzel and Couvillion (2002) have found strong correlations between urbanization and concentrations of fecal indicator bacteria in surface water. The same research indicates that significantly higher concentrations of fecal indicator bacteria were present in watersheds with sanitary sewers than those served primarily by septic systems, although this difference may be caused by the presence of storm sewers in addition to sanitary sewers in these more urbanized watersheds.
Most of these later studies can be characterized as gradient studies (McMahon and Cuffney, 2000); that is, they use data collected over short time periods from several geologically similar watersheds with varying degrees of human influences and evaluate effect based on correlation analysis. In essence, these studies substitute change through space for change through time. These techniques are useful in specific applications and allow the use of data collected with a standard set of methods specifically for the study. However, these gradient methods are not particularly sensitive to changes across fixed-time intervals.

Both the cumulative and gradient approaches make an implicit assumption that the hydrologic systems have equilibrated to changes in the watershed. This assumption is difficult to verify, and may in fact be technically invalid in many instances, because the land-cover change within the watershed is ongoing. However, the watersheds discussed herein are relatively small and would be expected to respond quickly to change. This study employs both techniques to assess the cumulative effect of land-use change in Oakland County (fig. 1), as well as the incremental effect of change since the late 1960s.

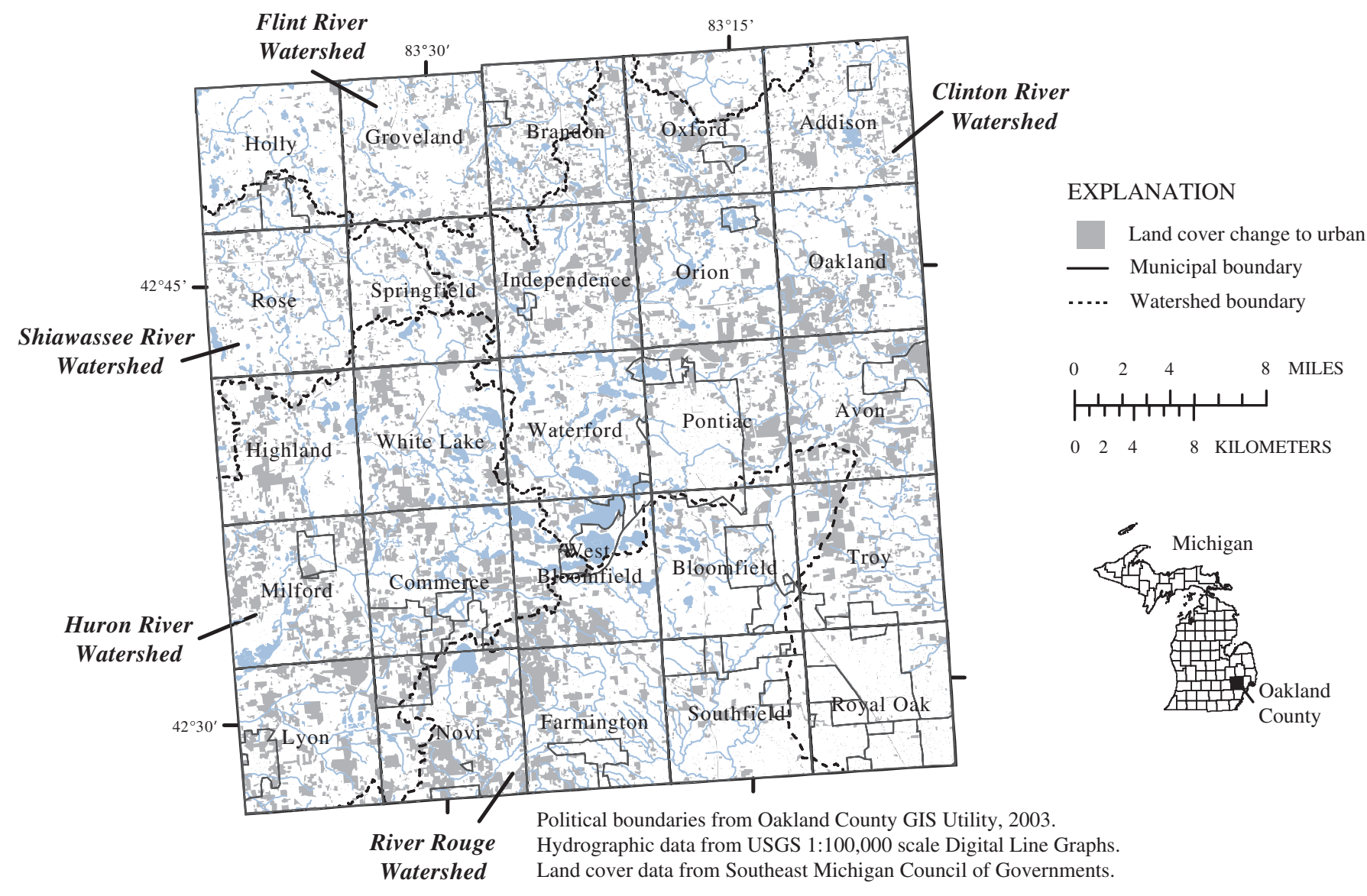

Figure 1. Conversion of land to urban cover in Oakland County, Mich, between 1980 and 2000. 


\section{Methods}

In order to quantify the effects of land-cover and population change on water resources, the data used in the analysis must first be standardized across both the period of study and the area of study. These standardized datasets can then be used for analysis. The next several sections describe the methods applied to the five land-cover datasets, three population data sets, continuous stream flow, and discrete water-quality samples.

\section{Land-cover and Population Analysis}

Land-cover data for the years 1985, 1990, 1995, and 2000 were obtained from Southeast Michigan Council of Governments (SEMCOG; Lisa Mayoras, written commun., 2003). Land-cover data for the year 1980 were obtained from the Michigan Geographic Data Library (Michigan Center for Geographic Information, 2002). Population data for the period from 1950 through 2000 were obtained from SEMCOG (Ann Burns, written commun., 2003). Standardization of both the spatial and attribute content of the datasets was a primary concern in ensuring that land-cover changes identified were indeed true changes, not the result of positional or classification differences between datasets.

Classification errors result from differences in attribution standards, either among photo interpreters in a single time period or between different mapping efforts. The more specific the classification, the more subjective error will be introduced. For instance, a light-industrial parcel could easily be confused for a commercial parcel based on aerial photography, but both would unquestionably be classified as "urban." In a wet year, a lowland forest may be classified as a wooded wetland. Although all data were developed by visual classification of aerial imagery, differences in standards, classification schemes, and even software result in small differences between data sets. The datasets used in this project were created at five different times over a period of approximately 20 years by countless individual photointerpreters. Consistency within one mapping effort might be possible, but complete consistency through the entire data series is unlikely. Further, the classification system itself changed slightly through time, resulting in slight inconsistency.

Spatial errors are characterized by the assignment of different boundaries to a feature with the same attribute content in two datasets. These errors result from differences in registration standards, changes in software or processing standards, and differences in the real or interpreted position of a class boundary. For example, the several interpreters may draw the boundary of a wetland or farmstead differently despite using the same source image. Frequently these types of errors are manifest as "slivers" - small areas where the boundaries of mapped areas do not coincide. Although individual slivers may cancel each other out, a systematic misregistration between datasets can result in more change being detected than has actually occurred. Methods were developed to collapse hydrologically similar classifications into larger groups and to identify a rasterization scale that would minimize positional errors by generalizing boundaries while maintaining the integrity of the source data.

\section{Land-cover-data standardization}

Land-cover data were collected by SEMCOG for five discrete time periods. Although all data were created by visual classification of aerial imagery, differences in standards, classification schemes, and even software have resulted in small differences between data sets. The datasets were standardized for both positional and classification accuracy by reclassification and rasterization, respectively.

Land-cover data were reclassified to provide attribute accuracy to address specific questions. The first set of questions relate generally to the effect of landcover change on hydrology. The resulting map, figure 2 , shows residential, commercial, and other built features, as well as agriculture, open land, forest, wetland, and open water. The land-cover data were also reclassified to differentiate densities of residential space for subsequent distribution of population. In this case, only residential space was identified, including high-rise multifamily, low-rise multifamily, detached single-family or duplex, mobile home parks, and farmsteads. All other space was classified as non-residential. Thus, for each time period, two land-cover maps were generated, one showing overall land cover at a level of detail similar to a one-digit Anderson classification (Anderson and others, 1976) and the second showing only residential space, classified to a level of detail similar to a threedigit Anderson classification.

To address small inconsistencies in the spatial registration of the dataset, as well as to facilitate processing, the original vector land-cover data were converted to raster (gridded) data. Selection of an appropriate cell size was based on balancing two conflicting goals: although larger cell sizes minimize the effect of small spatial registration errors, larger cell sizes also lead to over-representation of dominant cover types (Turner and others, 1989). Therefore, a series of grids were generated with cell sizes ranging from $1 \mathrm{~m}$ to $300 \mathrm{~m}$, and the relative representation of each land-cover class at each cell size was tabulated and graphed. An arbitrary threshold was set specifiying the largest cell size that resulted in less than 1 percent change in representation for any cover type in either the general land-cover or population 
$\begin{array}{lllll}\text { R. 7E } & \text { R. 8E } & \text { R. 9E } & \text { R. 10E } & \text { R. 11E }\end{array}$

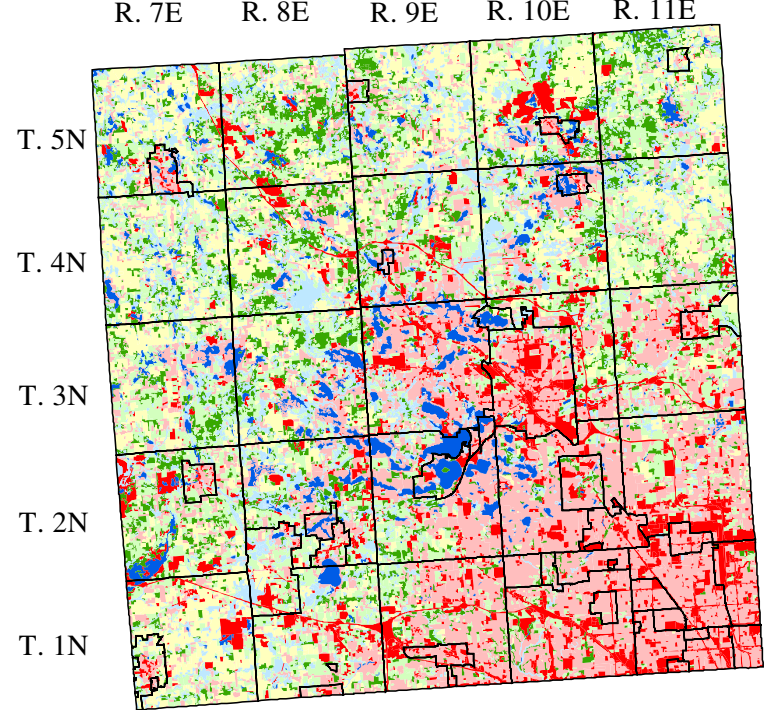

Land use/land cover, 1980

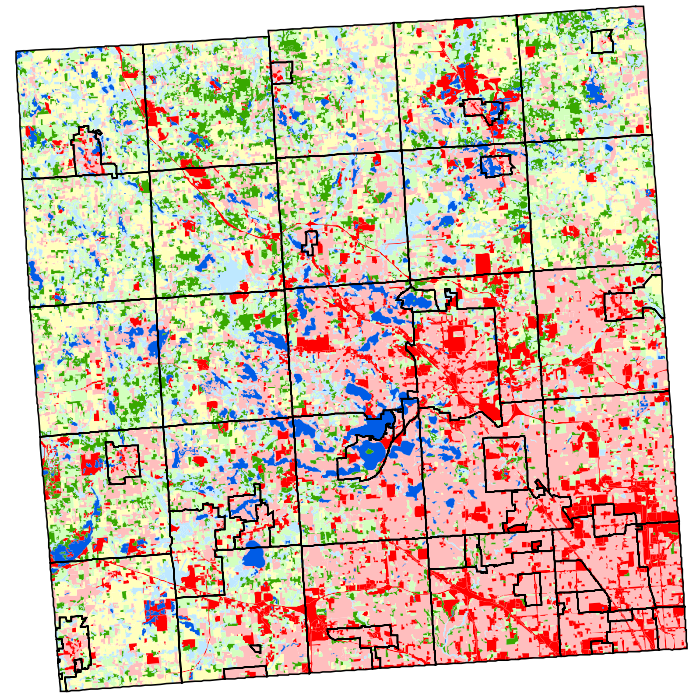

Land use/land cover, 1990

\section{Explanation}

Scale 1:700,000

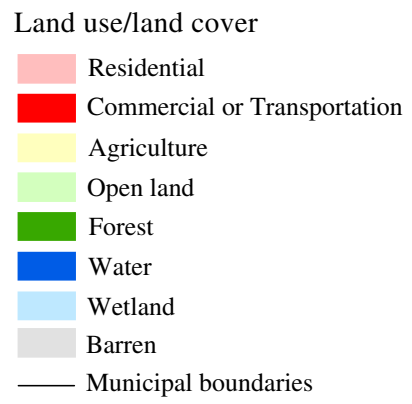

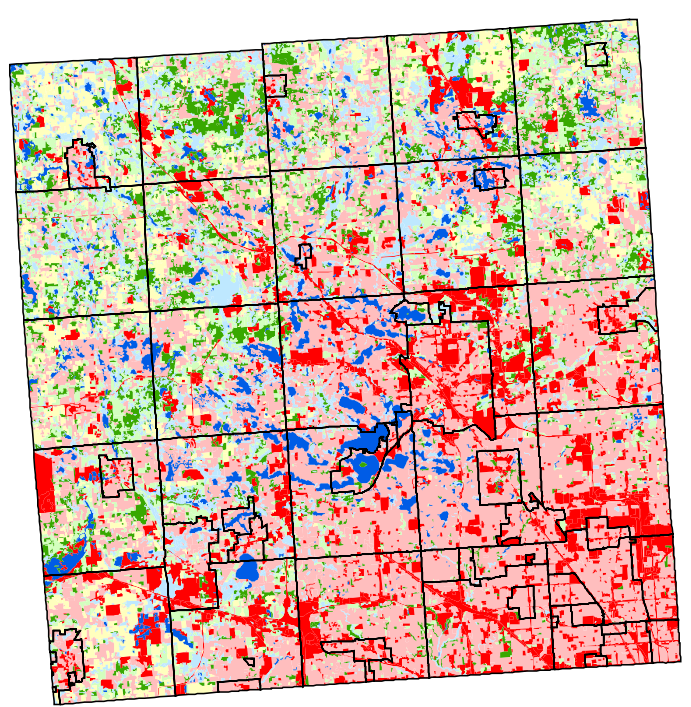

Land use/land cover, 2000

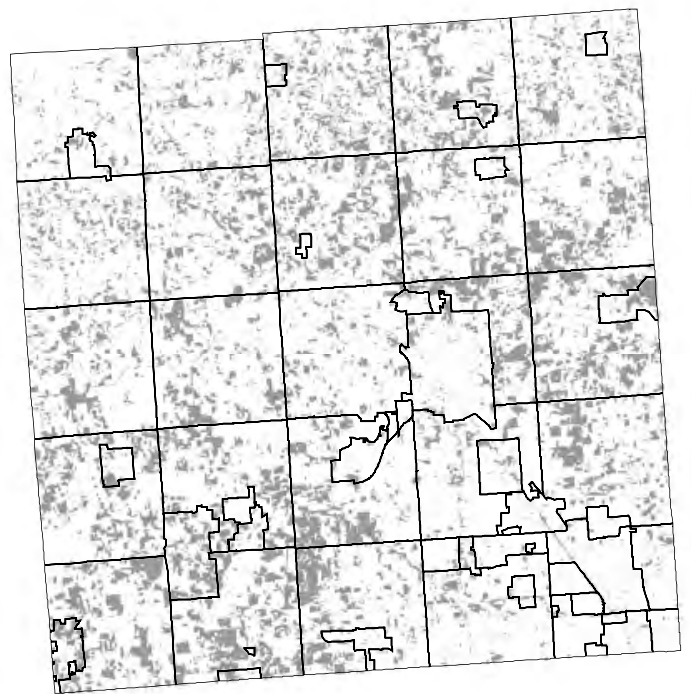

Land converted to urban use, 1980 to 2000

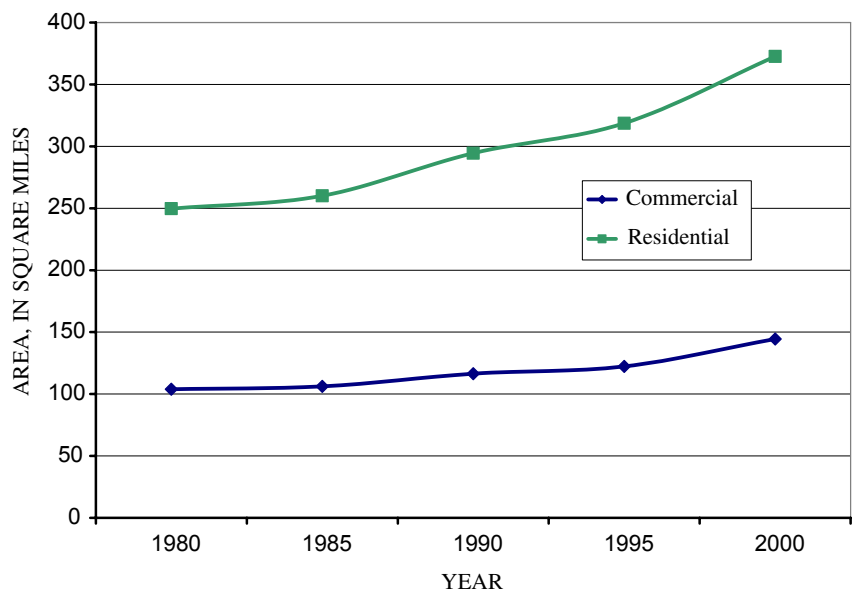

Figure 2. Land-use/land-cover change in Oakland County, Mich, between 1980 to 2000. 
classifications. Figure 3 and table 1 show the change in cover representation for the general land-cover classification for Oakland County as a whole. In this case, a 60-m cell size was selected. On the basis of the same criteria, population data were rasterized at a $20-\mathrm{m}$ cell size.

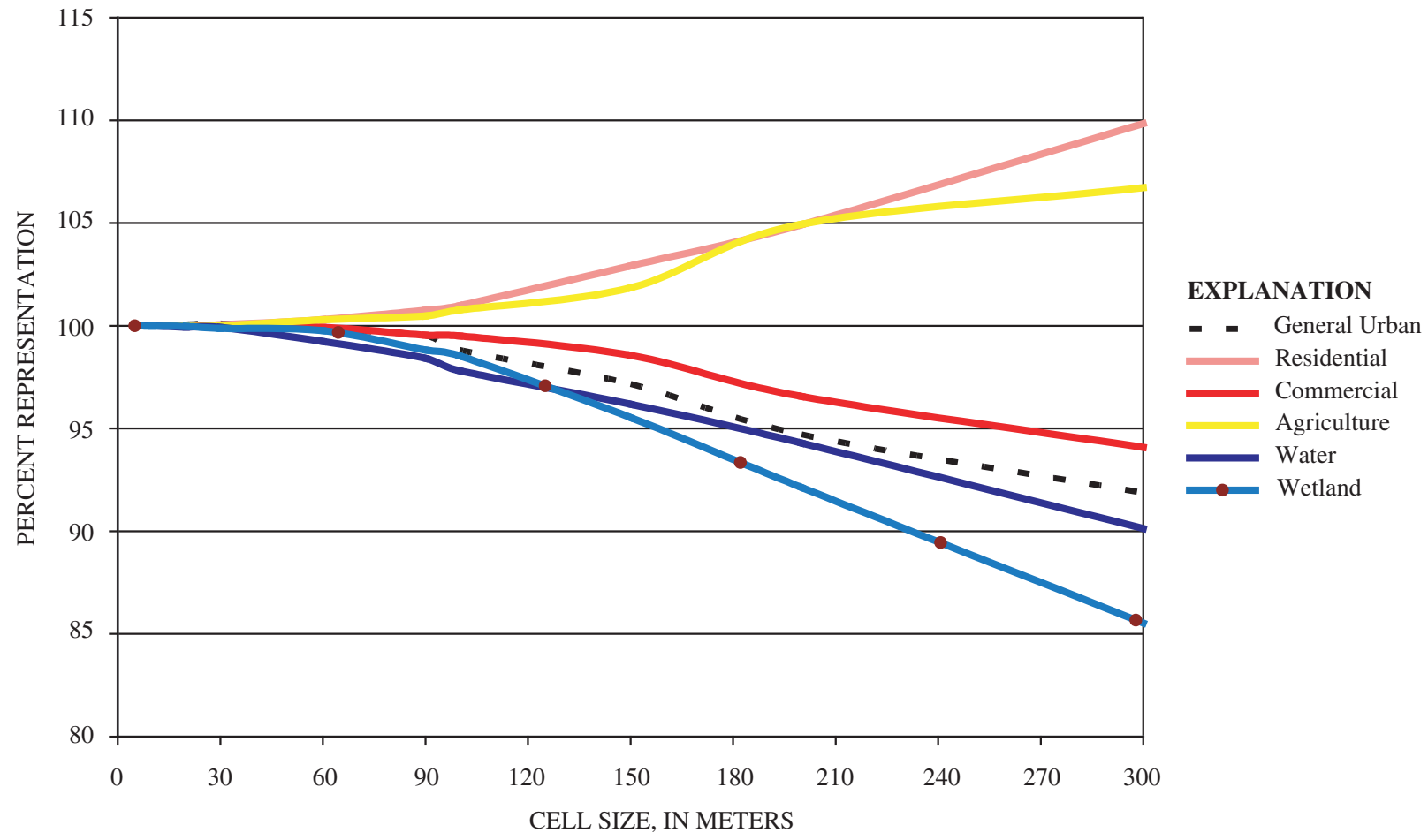

Figure 3. Relative landscape representation for selected land covers at various cell sizes.

Table 1. Relative percent landscape representation for selected land covers at various cell sizes.

[Cell sizes in meters on a side; all values in percent]

\begin{tabular}{lcccccccccc}
\hline & & \multicolumn{1}{c}{ Cell size } \\
Land-cover type & $\mathbf{5}$ & $\mathbf{1 0}$ & $\mathbf{2 0}$ & $\mathbf{3 0}$ & $\mathbf{6 0}$ & $\mathbf{9 0}$ & $\mathbf{1 0 0}$ & $\mathbf{1 5 0}$ & $\mathbf{2 0 0}$ & $\mathbf{3 0 0}$ \\
\hline Undifferentiated urban & 100 & 100 & 100 & 100 & 100 & 100 & 99 & 97 & 95 & 92 \\
Residential & 100 & 100 & 100 & 100 & 100 & 101 & 101 & 103 & 105 & 110 \\
Commercial & 100 & 100 & 100 & 100 & 100 & 100 & 100 & 99 & 97 & 94 \\
Agricultural & 100 & 100 & 100 & 100 & 100 & 100 & 101 & 102 & 105 & 107 \\
Open space & 100 & 100 & 100 & 100 & 100 & 100 & 100 & 99 & 99 & 96 \\
Forest & 100 & 100 & 100 & 100 & 100 & 99 & 99 & 97 & 94 & 87 \\
Water & 100 & 100 & 100 & 100 & 99 & 98 & 98 & 96 & 94 & 90 \\
Wetland & 100 & 100 & 100 & 100 & 100 & 99 & 99 & 96 & 92 & 86 \\
Barren & 100 & 99 & 101 & 92 & 101 & 75 & 124 & 70 & 124 & 0 \\
\hline
\end{tabular}




\section{Population-Data Standardization}

In order to accurately describe the effect of population density on water resources, it was first necessary to develop population densities based on watershed boundaries. However, population data are seldom, if ever, generated with reference to watershed boundaries. Population data are usually based on a set of nested polygons describing blocks, tracts, block groups, precincts, minor civil divisions (MCDs), counties, or other nonhydrologic units. Although tempting to simply overlay a watershed on these units and assign area-weighted densities from the census units to the watershed, such an approach makes the implicit assumption that population is distributed evenly across the census unit, which is frequently not the case.

This problem of the uneven distribution of a property within an arbitrary area has been identified as the modifiable areal unit problem, or MAUP, by Openshaw (1983) and several subsequent authors. The MAUP, stated simply, is that the summary characteristics of an area change as the boundaries of the area change. For example, redrawing a census boundary, even if the new polygon has the same area, will likely result in a different population value because the property of population is not uniformly distributed. Thus, altering the boundaries of the original census polygon, as in an overlay, alters the data values associated with the polygon. Rather than split the polygon, one must disaggregate the summary information within the polygon, then reaggregate it to a new set of boundaries. One approach commonly used is dasymetric mapping.

Dasymetric mapping uses ancillary information to distribute the characteristic of interest, in this case population, within the original census polygon. The technique was first described by Wright (1936) where population was distributed within municipalities on Cape Cod on the basis of road density. Monmonier and Schnell (1984) approached the problem by distinguishing residential land from other land-cover types on the basis of 1:250,000 scale land-cover data. Eicher and Brewer (2001) experimented with a set of approaches that assigned relative densities to land-cover classes within the civil mapping units. More recently, Mennis (2003) demonstrated a technique that samples population density from census polygons with uniform land cover to assign a density to the land cover, then applies that population density for all instances of that land cover. The advantage of this last technique is that more land-cover types can be used to distribute population. Two key disadvantages are the need for at least one population mapping unit solely comprised of a single land cover, and the assumption that there is no trend in density within individual land-cover classes across the study area. Within the study area, entire census polygons with uniform land cover were not available for most residential land covers.
For this study, the methods of Monmonier and Schnell (1984) and Mennis (2003) were combined. First, the land cover data for 1980, 1990, and 2000 were separated into residential and nonresidential groups. Nonresidential land, such as forest, industrial, and water are assumed to have no population density. Five residential land covers were identified and tabulated for 234 MCDs in southeast Michigan. A first estimate, based on Monmonier and Schnell (1984), would be to simply divide the population in the MCD by the residential area to arrive at a residential population density for the MCD. This value generally reflects differences in density across the urban gradient but does not utilize the full range of data available. Rather, relative weight coefficients were obtained by solving a series of simultaneous equations.

The dominant residential land cover by area in every MCD in each of the three time periods with population data is detached single family, comprising between 53 and 100 percent of the residential land cover. This residential land cover is the norm and is assigned a coefficient of 1 . When the coefficient is multiplied by the average residential population density for an MCD (described above), the result is the actual residential population density for the MCD. This simultaneously sets a "typical" density based on the most abundant housing classification and furnishes an overall density adjustment to account for differences along the urban gradient. A set of simultaneous equations was developed to assign a relative density to the other four classes, with the constraints that multifamily high-rise residential must have a greater density than multifamily low-rise residential, which in turn must have a greater density than detached singlefamily dwellings or mobile home park. Farmstead was specified as the lowest density residential cover.

The assumption is made that the relative change in density between land-cover classes was constant. Expressed slightly differently, although the absolute density (expressed as people per unit area) of multifamily low-rise housing, for example, is undoubtedly higher in the urban cores compared to rural areas, the relative density of multifamily low-rise housing compared to single-family, detached housing is assumed to be roughly constant. This assumption is based on the market principle that the factors driving housing density - the supply of land and the demand for housing - operate similarly across the region.

By solving this set of simultaneous equations, multifamily high rise was found to have a population density 3.6 times greater than detached single family, multifamily low rise was found to have a density 1.6 times greater than single-family detached, mobile home parks were found to have a density 1.1 times as great as single-family detached, and farmsteads were found to have a density 0.50 times as great as single-family detached in the year 2000. Coefficients for each residential land cover in each timeframe are in table 2. 
Table 2. Fitted population-density coefficients by year for each residential land-use/land-cover class in southeast Michigan.

[Note: these values must be multiplied by the average residential population density in each municipality to arrive at a true density]

\begin{tabular}{lccc}
\hline & \multicolumn{3}{c}{ Density Coefficient } \\
Land-use/land-cover class & $\mathbf{1 9 8 0}$ & $\mathbf{1 9 9 0}$ & $\mathbf{2 0 0 0}$ \\
\hline High-rise, multifamily residential & 13.40 & 12.00 & 3.64 \\
Low-rise, multifamily residential & 1.72 & 1.55 & 1.64 \\
Detached, single family & 1.00 & 1.00 & 1.00 \\
Mobile home park & 0.72 & 0.68 & 1.00 \\
Farmstead & 0.27 & 0.59 & 0.50 \\
\hline
\end{tabular}

The resulting density coefficients were multiplied by the area of each land-cover class within each MCD and new population totals. For example, Orion Township contained 0 cells of high-rise, multifamily (HRMF); 1,063 cells of low-rise, multifamily(LRMF); 42,037 cells of detached single-family/duplex (DSFD); 0 cells of mobile home parks (MHP); and 71 cells of farmsteads (FS). The overall residential density was 0.705 person per cell. Each cell is $400 \mathrm{~m}^{2}$. Thus, to calculate the estimated population, one would multiply each land cover by the overall density and the coefficient from table 2.

\begin{tabular}{|c|c|c|c|c|c|c|c|}
\hline Cover & $\begin{array}{l}\text { Area } \\
\text { (cells) }\end{array}$ & & $\begin{array}{c}\text { Overall density } \\
\text { (persons per cell) }\end{array}$ & & Coefficient & & $\begin{array}{l}\text { Product } \\
\text { (persons) }\end{array}$ \\
\hline HRMF & 0 & $\mathrm{x}$ & .705 & $\mathrm{x}$ & 3.6 & $=$ & 0 \\
\hline LRMF & 1,063 & $\mathrm{x}$ & .705 & $\mathrm{x}$ & 1.7 & $=$ & 1,300 \\
\hline DSFD & 42,037 & $\mathrm{x}$ & .705 & $\mathrm{x}$ & 1.0 & $=$ & 30,000 \\
\hline MHP & 0 & $\mathrm{x}$ & .705 & $\mathrm{x}$ & 1.0 & $=$ & 0 \\
\hline FS & 71 & $\mathrm{x}$ & .705 & $\mathrm{x}$ & 0.5 & $=$ & 25 \\
\hline
\end{tabular}

This result is 1.8 percent higher than the population of exactly 30,748 reported by SEMCOG, although some of that difference is the result of rounding to include only significant figures.

The intent of the exercise is not to model characteristics but rather to develop a method of distributing population across a mapping unit. Comparing the distributed population to the composite MCD level estimates produces an unbiased fit with a correlation of 0.9995. This approach does not fully meet Tobler's (1979) requirement that such a mapping be pycnophylactic; that is, that people are neither created nor destroyed in the redistribution process. Throughout the seven-county region, approximately 130,000 people were "created," out of a total population of 4.8 million. The majority of these errors were in Detroit and in several of the very rural MCD's, which represent the highest and lowest densities in the study area, respectively. This overall error level is appropriate to the analysis needs of this study.

The result is a raster map of population density expressed as persons per cell, in this case a $20-\mathrm{m}$ by 20 $\mathrm{m}$ grid cell. This density map can then be overlain with the watershed boundaries to arrive at population density characteristics for each watershed area.

\section{Hydrologic Data}

Three major types of hydrologic data are discussed in this report; continuously measured streamflow, continuously measured specific conductance, and discretely measured water-quality data from 1966-1970 and 2001-2003. Locations where streamflow or specific conductance was monitored, or samples were collected, are shown in figure 4. Data collected during the 20012003 collection effort can be found in Aichele and others (2004). Data collected during the 1966-1970 sampling efforts can be found in Michigan District annual data reports from the appropriate year, as well as the USGS National Water Information System database (NWIS) (U.S. Geological Survey, 2003).

\section{Streamflow Data}

Continuous daily streamflow data for the period 1970 through 2003 were obtained from the USGS NWIS database. Although most streamflow-gaging stations were operated continuously throughout the period, several stations were discontinued for one or more years. A complete listing of station identifiers, descriptions, and years operated is given in table 3 . 


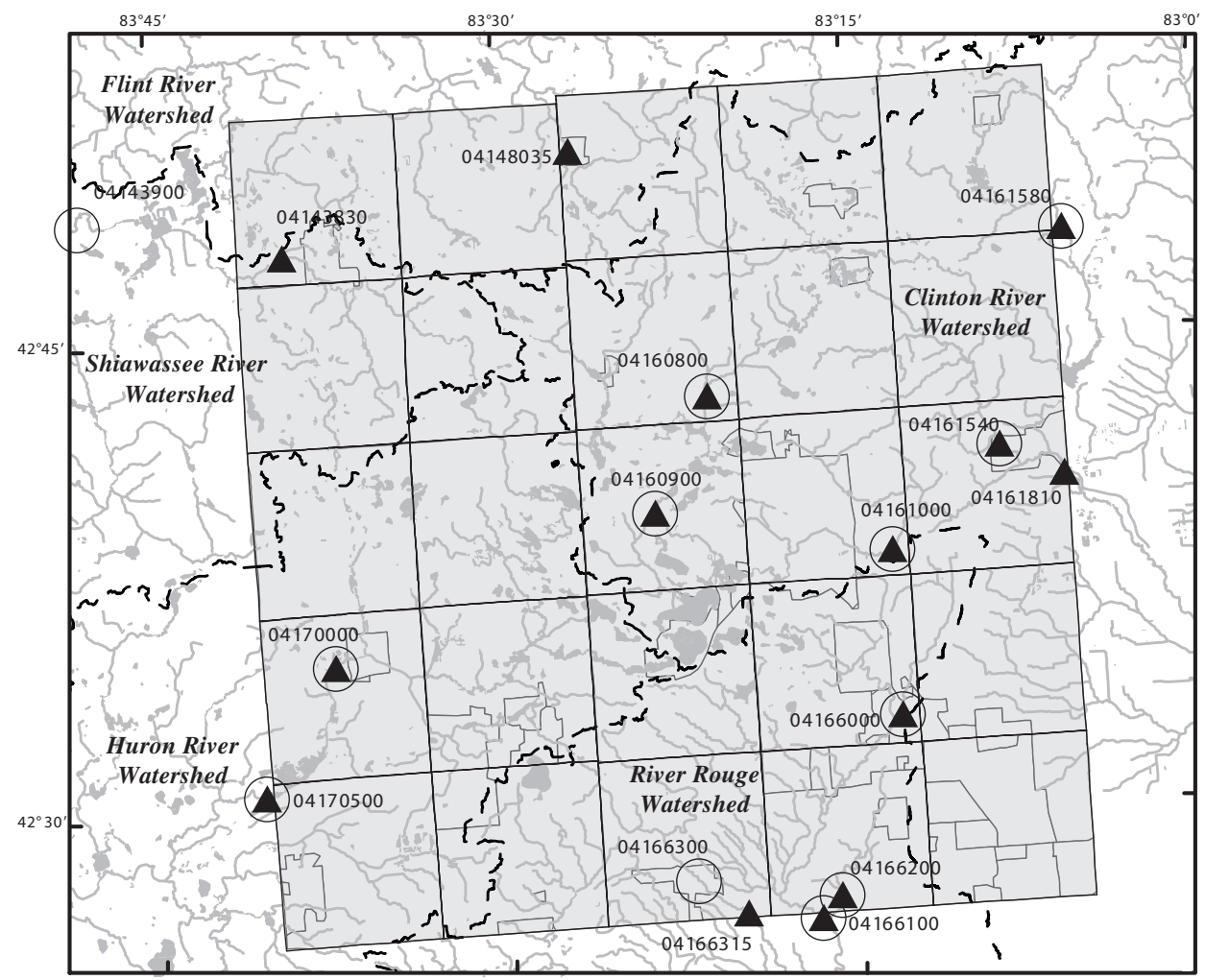

EXPLANATION

Streamflow-monitoring station

Stream water-quality

- sample locations

- Municipal boundary

--- Watershed boundary
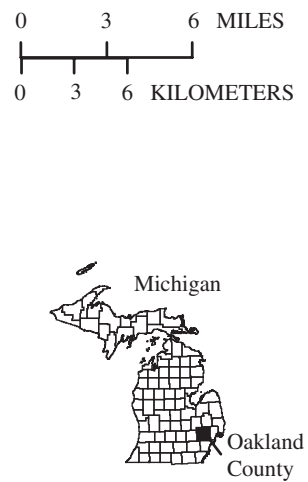

Political boundaries from Oakland County GIS Utility, 2003.

Hydrographic data from USGS 1:100,000 scale Digital Line Graphs.

Figure 4. Locations of discrete water-quality sample sites, continuous streamflow-gaging stations, and specific conductance monitors.

Table 3. Identification and period of record for streamflow-gaging stations used in this study.

[Refer to figure 4 for station locations]

\begin{tabular}{|c|c|c|c|c|}
\hline Station number & Station name & Year constructed & Years inactive & $\begin{array}{l}\text { Drainage area } \\
\text { (square miles) }\end{array}$ \\
\hline 04143900 & Shiawassee River at Linden, Mich. & 1967 & 1994-2001 & 49.2 \\
\hline 04148140 & Kearsley Creek near Davison, Mich. & 1965 & -- & 19.6 \\
\hline 04160800 & Sashabaw Creek near Drayton Plains, Mich. & 1959 & -- & 20.9 \\
\hline 04160900 & Clinton River near Drayton Plains, Mich. & 1959 & -- & 79.2 \\
\hline 04161000 & Clinton River at Auburn Hills, Mich. & 1939 & $1940-1956, \quad 1982-2001 *$ & 123 \\
\hline 04161540 & Paint Creek at Rochester, Mich. & 1959 & -- & 70.9 \\
\hline 04161580 & Stony Creek near Romeo, Mich. & 1964 & -- & 25.6 \\
\hline 04164000 & Clinton River near Fraser, Mich. & 1947 & -- & 299 \\
\hline 04166000 & River Rouge at Birmingham, Mich. & 1950 & -- & 33.3 \\
\hline 04166100 & River Rouge at Southfield, Mich. & 1958 & -- & 87.9 \\
\hline 04166200 & Evans Ditch at Southfield, Mich. & 1958 & -- & 9.49 \\
\hline 04166300 & Upper River Rouge at Farmington, Mich. & 1958 & -- & 17.5 \\
\hline 04170000 & Huron River at Milford, Mich. & 1948 & -- & 132 \\
\hline 04170500 & Huron River near New Hudson, Mich. & 1948 & -- & 148 \\
\hline
\end{tabular}

* Station 04161000 was operated as a crest-stage gage from 1982 to 1991 and throughout water year 2003. 


\section{Discrete Water-Quality Data}

Water-quality results for 19 sites in Oakland County are provided in USGS Water-Supply Paper 2000 (Twenter and Knutilla, 1972). Nine of these sites were sampled once only in 1966, and ten were sampled twice. No site was sampled more than twice. The characteristics measured included temperature, $\mathrm{pH}$, specific conductance, bicarbonate $\left(\mathrm{HCO}_{3}\right)$, carbonate $\left(\mathrm{CO}_{3}\right)$, sulfate $\left(\mathrm{SO}_{4}\right)$, chloride $(\mathrm{Cl})$, fluoride $(\mathrm{F})$, nitrate $\left(\mathrm{NO}_{3}\right)$, phosphate $\left(\mathrm{PO}_{4}\right)$, dissolved solids, total hardness, and noncarbonate hardness. Low-flow water-quality samples were also collected from specific sites and analyzed for specific subsets of these characteristics during water years 1967-1970.

For comparison, 14 sites were sampled between 4 and 18 times during September 2001 through September 2003 under varying flow conditions. At each site, several samples were collected under spring and summer low-flow conditions to parallel the sample collection conditions of the 1966-1970 period. Low flow for these relatively small watersheds was defined as three or more consecutive days of declining discharge and instantaneous discharge below the 75th percentile of annual daily discharge. Twelve of the 14 sites were also sampled in 1966 (Twenter and Knutilla, 1972). One site, the Upper River Rouge near Clarenceville (04166315), was substituted for the Upper River Rouge at Farmington (04166300). A second site, Kearsley Creek at Mill Street at Ortonville, Mich. (04148035), was substituted for the site Kearsley Creek at Ortonville, Mich. (04148020). Both substitutions were slightly downstream from the previous study sites and were made because of concerns with access to the sites. Neither change involved the addition of significant tributaries. A complete list of the sites sampled in 2001 through 2003 is given in table 4 .

All samples were collected in accordance with standard protocols developed for the USGS National WaterQuality Assessment (NAWQA) as described in Shelton (1994). Eschericia coli (E. coli) were quantified at all sites on several occasions in accordance with the methods described in Myers and Sylvester (1997). Temperature, specific conductance, $\mathrm{pH}$, and dissolved oxygen were measured in the field with a multiparameter meter. Alkalinity and bicarbonate were determined in the field by titration. All other chemical analyses were done at the USGS National Water Quality Laboratory in Denver, Colo. A list of the characteristics measured, the methods used, and minimum reporting level (MRL) is given in Table 5. Detailed analytical results of the sample-collection and analytical methods are included in Aichele and others (2004).

Table 4. Sites where discrete water-quality samples were collected during 2001-2003.

[Sites marked with asterisks are also streamflow-gaging stations; refer to figure 4 for station locations]

\begin{tabular}{llc}
\hline Site number & \multicolumn{1}{c}{ Site name } & $\begin{array}{c}\text { Drainage area } \\
\text { (square miles) }\end{array}$ \\
\hline 04143830 & Shiawassee River near Holly, Mich. & 49.2 \\
04148035 & Kearsley Creek at Mill Street at Ortonville, Mich. & 20.1 \\
04160800 & Sashabaw Creek near Drayton Plains, Mich.* & 20.9 \\
04160900 & Clinton River near Drayton Plains, Mich.* & 79.2 \\
04161000 & Clinton River at Auburn Hills, Mich.* & 123.0 \\
04161540 & Paint Creek at Rochester, Mich.* & 70.9 \\
04161580 & Stony Creek near Romeo, Mich.* & 25.6 \\
04161810 & Clinton River at Yates, Mich. & 299.0 \\
04166100 & River Rouge at Southfield, Mich.* & 87.9 \\
04166200 & Evans Ditch at Southfield, Mich.* & 9.5 \\
04166315 & Upper River Rouge at Clarenceville, Mich. & 19.8 \\
04170000 & Huron River at Milford, Mich.* & 132.0 \\
04170500 & Huron River near New Hudson, Mich.* & 148.0 \\
\hline
\end{tabular}


Table 5. Water-quality characteristics and analytical methods for inorganic stream-water-quality samples collected in 0akland County, Michigan, during 2001, 2002, and 2003.

[MRL, Minimum Reporting Level; mg/L, milligrams per liter; ${ }^{\circ} \mathrm{C}$, degrees Celsius; $\mu \mathrm{g} / \mathrm{L}$, micrograms per liter; $\mu \mathrm{S} / \mathrm{cm}$, microsiemens per centimeter at 25 degrees Celsius]

\begin{tabular}{|c|c|c|c|c|c|}
\hline $\begin{array}{l}\text { Parameter } \\
\text { code }\end{array}$ & Characteristic & Units & MRL & Method & Reference \\
\hline 00095 & Specific conductance, field & $\mu \mathrm{S} / \mathrm{cm}$ & 1.0 & & Wilde and Radtke, 1998 \\
\hline 00400 & $\mathrm{pH}$, field & Standard units & 0.1 & & Wilde and Radtke, 1998 \\
\hline 00403 & $\mathrm{pH}$, laboratory & Standard units & .1 & I258785 & Fishman and Friedman, 1989 \\
\hline 00453 & Bicarbonate, field & $\mathrm{mg} / \mathrm{L}$ as $\mathrm{CaCO}_{3}$ & 1.0 & & Wilde and Radtke, 1998 \\
\hline 00530 & Residue, total & $\mathrm{mg} / \mathrm{L}$ & 1.0 & I376585 & Fishman and Friedman, 1989 \\
\hline 00608 & Nitrogen, ammonia & $\mathrm{mg} / \mathrm{L}$ as $\mathrm{N}$ & .02 & I 252290 & Fishman, 1993 \\
\hline 00613 & Nitrogen, nitrite & $\mathrm{mg} / \mathrm{L}$ as $\mathrm{N}$ & .01 & $\mathrm{I} 254090$ & Fishman, 1993 \\
\hline 00623 & Nitrogen, ammonia \& organic & $\mathrm{mg} / \mathrm{L}$ as $\mathrm{N}$ & .1 & I261091 & Patton and Truitt, 1992 \\
\hline 00625 & Nitrogen, ammonia \& organic & $\mathrm{mg} / \mathrm{L}$ as $\mathrm{N}$ & .1 & I451591 & Patton and Truitt, 2000 \\
\hline 00631 & $\mathrm{NO}_{2}+\mathrm{NO}_{3}$, dissolved & $\mathrm{mg} / \mathrm{L}$ as $\mathrm{N}$ & .05 & I254590 & Fishman, 1993 \\
\hline 00665 & Phosphorus, total & $\mathrm{mg} / \mathrm{L}$ as $\mathrm{P}$ & .05 & I461091 & Patton and Truitt, 1992 \\
\hline 00666 & Phosphorus, dissolved & $\mathrm{mg} / \mathrm{L}$ as $\mathrm{P}$ & .004 & EPA365.1 & U.S. Environmental Protection Agency, 1994 \\
\hline 00671 & Phosphorus, orthophosphate & $\mathrm{mg} / \mathrm{L}$ as $\mathrm{P}$ & .01 & I260190 & Fishman, 1993 \\
\hline 00915 & Calcium, dissolved & $\mathrm{mg} / \mathrm{L}$ as $\mathrm{Ca}$ & .02 & I147287 & Fishman and Friedman, 1989 \\
\hline 00925 & Magnesium, dissolved & $\mathrm{mg} / \mathrm{L}$ as $\mathrm{Mg}$ & .004 & I147287 & Fishman, 1993 \\
\hline 00930 & Sodium, dissolved & $\mathrm{mg} / \mathrm{L}$ as $\mathrm{Na}$ & .06 & I147287 & Fishman, 1993 \\
\hline 00935 & Potassium, dissolved & $\mathrm{mg} / \mathrm{L}$ as $\mathrm{K}$ & .1 & I163085 & Fishman and Friedman, 1989 \\
\hline 00940 & Chloride, dissolved & $\mathrm{mg} / \mathrm{L}$ as $\mathrm{Cl}$ & .1 & I205785 & Fishman and Friedman, 1989 \\
\hline 00945 & Sulfate, dissolved & $\mathrm{mg} / \mathrm{L}$ as $\mathrm{SO}_{4}$ & .1 & I205785 & Fishman and Friedman, 1989 \\
\hline 00950 & Fluoride, dissolved & $\mathrm{mg} / \mathrm{L}$ as $\mathrm{F}$ & .1 & I232785 & Fishman and Friedman, 1989 \\
\hline 00955 & Silica, dissolved & $\mathrm{mg} / \mathrm{L}$ as $\mathrm{SiO}_{2}$ & .1 & I270085 & Fishman and Friedman, 1989 \\
\hline 01046 & Iron, dissolved & $\mu \mathrm{g} / \mathrm{L}$ & 6.0 & I147287 & Fishman, 1993 \\
\hline 01056 & Manganese, dissolved & $\mu \mathrm{g} / \mathrm{L}$ & 6 & I147287 & Fishman, 1993 \\
\hline 39086 & Alkalinity, dissolved, field & $\mathrm{mg} / \mathrm{L}$ as $\mathrm{CaCO}_{3}$ & 1.0 & I203085 & Fishman and Friedman, 1989 \\
\hline 70300 & Dissolved solids, residue at $180^{\circ} \mathrm{C}$ & $\mathrm{mg} / \mathrm{L}$ & 10.0 & $\mathrm{I} 175085$ & Fishman and Friedman, 1989 \\
\hline 90095 & Specific conductance, laboratory & $\mu \mathrm{S} / \mathrm{cm}$ & 1.0 & I278185 & Fishman and Friedman, 1989 \\
\hline 90410 & Acid neutralizing capacity, laboratory & $\mathrm{mg} / \mathrm{L}$ as $\mathrm{CaCO}_{3}$ & 1.0 & I203085 & Fishman and Friedman, 1989 \\
\hline
\end{tabular}

\section{Streamflow Characteristics}

Three measures of streamflow characteristics were computed: low flow, high flow, and flashiness of the stream. These measures were the 99-percent exceedance flow, the 1-percent exceedance flow, and the standard deviation of the data values, respectively (Richter and others, 1996). From October 1, 1970 to September 30, 2003, daily flows were used and statistics computed by water year. These flow values were not adjusted for drainage area because the temporal analysis only compared values for one watershed through time. For June 2001 through September 30, 2003, hourly flows were used and statistics computed for the entire period. Hourly flows were adjusted to normalize for drainage area so that flows could be compared across watersheds of differing areas. 
The continuous streamflow-gaging stations used in this analysis are all operated by the U.S. Geological Survey. Locations of the streamflow-gaging stations are shown in figure 4 , and station identification number, the name of the stations, and the period of available record are listed in table 3. Although daily flows are available for most stations throughout 1970-2003, several stations were not operated continuously within the 33-year period. Instantaneous data are available for the period October 1992 to present (2004). Daily streamflow data are not as sensitive to changes in stream response to precipitation as instantaneous flows, which are typically recorded at 15-minute intervals; however, the record of such instantaneous flows only extends back to 1992 , whereas daily values are available for the entire period of record.

\section{Discrete Water-Quality Comparison}

During 1966 through 1970, the USGS did some limited low-flow water-quality sampling at sites throughout Oakland County. Although this sampling effort was limited in both number of samples and chemical scope, the results can be used for comparison to data produced during 2001 through 2003. Data from each time period were grouped by site, and geometric means were calculated for each water-quality characteristic common to both sampling efforts. In samples where a specific chemical characteristic was not detected at a concentration above the MRL listed in table 5, the MRL was used in calculating the geometric mean. These two datasets were then compared for increases and decreases in each characteristic at each site.

\section{Correlations Among Watersheds Across the Urban Gradient}

Land-cover and population-density data reflective of the year 2000 were collected at the watershed scale and compared to instantaneous streamflow characteristics measured between 2000 and 2003, as well as geometric means of selected water-quality characteristics at the 14 water- quality sampling locations. This analysis shows most of the expected effects of urban land, including effects on streamflow characteristics and water quality.

\section{Changes in Land Cover and Population Density}

The results of the land-cover-change analysis on the watershed level are presented in table 6 . The overall rate of land-cover change was most rapid in the least urbanized areas, although even the heavily urbanized watersheds of the River Rouge watershed continued to develop. The change in built landscape is shown at the right side of table 6 .

Table 6. Land-use/land-cover composition of monitored watersheds in Oakland County, Michigan, 1980 to 2000.

[All land-use/land-cover data in percent; refer to figure 4 for station locations]

\begin{tabular}{|c|c|c|c|c|c|c|c|c|c|c|c|}
\hline \multirow[b]{2}{*}{$\begin{array}{l}\text { Station } \\
\text { number }\end{array}$} & \multirow[b]{2}{*}{ Year } & \multirow[b]{2}{*}{ Built $^{1}$} & \multirow[b]{2}{*}{ Residential } & \multirow[b]{2}{*}{ Commercial } & \multirow[b]{2}{*}{ Agricultural } & \multirow[b]{2}{*}{$\begin{array}{c}\text { Open } \\
\text { Space }\end{array}$} & \multirow[b]{2}{*}{ Forest } & \multirow[b]{2}{*}{ Water } & \multirow[b]{2}{*}{ Wetland } & \multicolumn{2}{|c|}{ Total } \\
\hline & & & & & & & & & & Built & Unbuilt \\
\hline \multirow{5}{*}{04143830} & 1980 & 2.4 & 10.7 & 1.1 & 30.5 & 22.3 & 13.3 & 3.5 & 16.3 & 14.2 & 85.8 \\
\hline & 1985 & 2.7 & 10.8 & 1.1 & 30.4 & 22.2 & 13.2 & 3.5 & 16.2 & 14.5 & 85.5 \\
\hline & 1990 & 2.6 & 13.9 & 1.2 & 28.4 & 21.3 & 13.1 & 3.5 & 16.0 & 17.7 & 82.3 \\
\hline & 1995 & 2.8 & 15.9 & 1.2 & 27.5 & 20.5 & 12.6 & 3.5 & 16.0 & 19.9 & 80.1 \\
\hline & 2000 & 3.0 & 24.8 & 1.5 & 17.1 & 20.3 & 13.2 & 3.9 & 16.2 & 29.3 & 70.7 \\
\hline \multirow{5}{*}{04148035} & 1980 & 0.7 & 16.2 & 1.0 & 23.9 & 23.4 & 17.5 & 3.5 & 13.9 & 17.8 & 82.2 \\
\hline & 1985 & 0.7 & 17.2 & 0.9 & 23.4 & 23.2 & 17.3 & 3.6 & 13.8 & 18.8 & 81.2 \\
\hline & 1990 & 0.6 & 20.9 & 1.0 & 22.3 & 21.6 & 17.0 & 3.6 & 13.0 & 22.5 & 77.5 \\
\hline & 1995 & 0.6 & 24.6 & 1.2 & 20.6 & 19.9 & 16.1 & 3.6 & 13.4 & 26.5 & 73.5 \\
\hline & 2000 & 1.0 & 32.8 & 1.6 & 12.1 & 17.8 & 15.5 & 3.9 & 15.4 & 35.3 & 64.7 \\
\hline \multirow{5}{*}{04160800} & 1980 & 3.6 & 19.3 & 2.0 & 11.5 & 29.2 & 7.4 & 6.0 & 21.1 & 24.9 & 75.1 \\
\hline & 1985 & 3.6 & 20.4 & 4.5 & 10.6 & 26.9 & 7.3 & 6.0 & 20.8 & 28.5 & 71.5 \\
\hline & 1990 & 4.1 & 24.1 & 5.7 & 9.1 & 23.6 & 6.9 & 6.0 & 20.5 & 33.9 & 66.1 \\
\hline & 1995 & 4.9 & 27.5 & 5.6 & 6.9 & 22.0 & 6.6 & 6.0 & 20.5 & 38.0 & 62.0 \\
\hline & 2000 & 6.8 & 36.1 & 7.3 & 3.9 & 15.7 & 5.1 & 6.0 & 19.1 & 50.2 & 49.8 \\
\hline
\end{tabular}

${ }_{1}^{1}$ Undifferentiated urban land, not clearly identified as commercial or residential. 
Table 6. Land-use/land-cover composition of monitored watersheds in Oakland County, Michigan, 1980 to 2000.

[All land-use/land-cover data in percent; refer to figure 4 for station locations]

\begin{tabular}{|c|c|c|c|c|c|c|c|c|c|c|c|}
\hline \multirow[b]{2}{*}{$\begin{array}{l}\text { Station } \\
\text { number }\end{array}$} & \multirow[b]{2}{*}{ Year } & \multirow[b]{2}{*}{ Built ${ }^{1}$} & \multirow[b]{2}{*}{ Residential } & \multirow[b]{2}{*}{ Commercial } & \multirow[b]{2}{*}{ Agricultural } & \multirow[b]{2}{*}{$\begin{array}{c}\text { Open } \\
\text { Space }\end{array}$} & \multirow[b]{2}{*}{ Forest } & \multirow[b]{2}{*}{ Water } & \multirow[b]{2}{*}{ Wetland } & \multicolumn{2}{|c|}{ Total } \\
\hline & & & & & & & & & & Built & Unbuilt \\
\hline \multirow{5}{*}{04160900} & 1980 & 4.6 & 27.8 & 4.8 & 9.0 & 22.7 & 10.2 & 8.5 & 12.5 & 37.2 & 62.8 \\
\hline & 1985 & 4.7 & 28.6 & 5.6 & 8.6 & 21.7 & 10.0 & 8.6 & 12.3 & 38.9 & 61.1 \\
\hline & 1990 & 4.8 & 32.3 & 6.2 & 7.7 & 18.8 & 9.5 & 8.6 & 12.2 & 43.2 & 56.8 \\
\hline & 1995 & 5.0 & 36.1 & 6.4 & 6.6 & 16.6 & 8.6 & 8.6 & 12.1 & 47.5 & 52.5 \\
\hline & 2000 & 6.1 & 43.8 & 7.9 & 3.6 & 11.8 & 6.6 & 8.6 & 11.6 & 57.7 & 42.3 \\
\hline \multirow{5}{*}{04161000} & 1980 & 5.3 & 32.0 & 9.6 & 6.3 & 18.1 & 7.6 & 10.2 & 11.0 & 46.8 & 53.2 \\
\hline & 1985 & 5.5 & 32.6 & 9.9 & 6.0 & 17.4 & 7.5 & 10.2 & 10.9 & 48.0 & 52.0 \\
\hline & 1990 & 5.2 & 35.3 & 10.9 & 5.4 & 15.1 & 7.2 & 10.2 & 10.7 & 51.4 & 48.6 \\
\hline & 1995 & 5.6 & 38.4 & 11.0 & 4.6 & 13.3 & 6.4 & 10.2 & 10.5 & 55.0 & 45.0 \\
\hline & 2000 & 6.4 & 44.3 & 12.5 & 2.5 & 9.3 & 4.8 & 10.3 & 10.0 & 63.1 & 36.9 \\
\hline \multirow{5}{*}{04161540} & 1980 & 4.6 & 19.8 & 1.9 & 23.8 & 25.8 & 9.0 & 3.4 & 11.7 & 26.3 & 73.7 \\
\hline & 1985 & 4.5 & 23.1 & 2.0 & 22.7 & 23.8 & 8.8 & 3.5 & 11.5 & 29.6 & 70.4 \\
\hline & 1990 & 4.9 & 27.3 & 2.3 & 20.7 & 21.1 & 8.5 & 3.7 & 11.4 & 34.6 & 65.4 \\
\hline & 1995 & 4.9 & 33.7 & 2.4 & 17.4 & 18.0 & 8.2 & 3.9 & 11.4 & 41.1 & 58.9 \\
\hline & 2000 & 5.4 & 43.9 & 3.1 & 9.2 & 15.3 & 7.1 & 4.0 & 11.9 & 52.4 & 47.6 \\
\hline \multirow{5}{*}{04161580} & 1980 & 1.2 & 10.3 & 0.3 & 24.4 & 30.5 & 15.1 & 3.8 & 14.6 & 11.7 & 88.3 \\
\hline & 1985 & 1.1 & 13.1 & 0.2 & 23.3 & 29.2 & 14.9 & 3.7 & 14.5 & 14.4 & 85.6 \\
\hline & 1990 & 1.2 & 19.0 & 0.4 & 20.8 & 26.6 & 14.1 & 3.7 & 14.3 & 20.5 & 79.5 \\
\hline & 1995 & 1.2 & 19.6 & 0.4 & 21.1 & 25.5 & 14.1 & 3.7 & 14.4 & 21.1 & 78.9 \\
\hline & 2000 & 3.0 & 24.7 & 2.4 & 13.2 & 22.1 & 16.0 & 4.3 & 14.2 & 30.2 & 69.8 \\
\hline \multirow{5}{*}{04161810} & 1980 & 5.9 & 23.5 & 5.6 & 14.5 & 23.8 & 9.5 & 6.0 & 11.1 & 35.1 & 64.9 \\
\hline & 1985 & 6.1 & 25.2 & 6.0 & 14.0 & 22.4 & 9.2 & 6.1 & 11.0 & 37.3 & 62.7 \\
\hline & 1990 & 6.1 & 28.6 & 7.0 & 12.6 & 19.9 & 8.8 & 6.2 & 10.8 & 41.7 & 58.3 \\
\hline & 1995 & 6.3 & 31.9 & 7.2 & 11.2 & 18.0 & 8.3 & 6.3 & 10.7 & 45.4 & 54.6 \\
\hline & 2000 & 7.1 & 38.4 & 8.9 & 7.3 & 13.9 & 7.6 & 6.4 & 10.6 & 54.3 & 45.7 \\
\hline \multirow{5}{*}{04166000} & 1980 & 4.7 & 57.7 & 7.3 & 3.3 & 12.0 & 5.3 & 4.6 & 5.0 & 69.8 & 30.2 \\
\hline & 1985 & 4.9 & 58.4 & 7.6 & 3.0 & 11.8 & 4.9 & 4.6 & 4.9 & 70.9 & 29.1 \\
\hline & 1990 & 5.5 & 64.1 & 9.2 & 1.4 & 6.7 & 3.8 & 4.6 & 4.7 & 78.8 & 21.2 \\
\hline & 1995 & 5.5 & 68.2 & 9.8 & 0.4 & 4.8 & 2.7 & 4.8 & 3.8 & 83.5 & 16.5 \\
\hline & 2000 & 5.7 & 70.0 & 10.7 & 0.4 & 2.8 & 2.3 & 4.8 & 3.4 & 86.3 & 13.7 \\
\hline \multirow{5}{*}{04166100} & 1980 & 6.0 & 61.2 & 7.8 & 2.3 & 10.6 & 5.8 & 2.8 & 3.6 & 75.0 & 25.0 \\
\hline & 1985 & 6.1 & 61.6 & 8.0 & 2.1 & 10.4 & 5.5 & 2.8 & 3.6 & 75.6 & 24.4 \\
\hline & 1990 & 6.6 & 65.8 & 9.7 & 0.8 & 6.3 & 4.5 & 2.8 & 3.4 & 82.1 & 17.9 \\
\hline & 1995 & 6.5 & 68.2 & 10.2 & 0.4 & 5.0 & 3.8 & 2.9 & 3.1 & 84.9 & 15.1 \\
\hline & 2000 & 6.7 & 70.6 & 11.0 & 0.2 & 2.7 & 3.2 & 2.9 & 2.8 & 88.3 & 11.7 \\
\hline \multirow{5}{*}{04166200} & 1980 & 6.5 & 64.1 & 18.4 & 0.0 & 7.2 & 3.0 & 0.0 & 0.7 & 89.0 & 11.0 \\
\hline & 1985 & 6.3 & 64.2 & 18.7 & 0.0 & 7.1 & 3.0 & 0.0 & 0.7 & 89.2 & 10.8 \\
\hline & 1990 & 7.6 & 65.0 & 19.8 & 0.0 & 3.9 & 3.0 & 0.0 & 0.7 & 92.4 & 7.6 \\
\hline & 1995 & 7.8 & 65.4 & 20.4 & 0.0 & 2.7 & 3.0 & 0.0 & 0.7 & 93.6 & 6.4 \\
\hline & 2000 & 8.1 & 65.7 & 21.0 & 0.0 & 1.8 & 2.8 & 0.0 & 0.7 & 94.8 & 5.2 \\
\hline
\end{tabular}

${ }^{1}$ Undifferentiated urban land, not clearly identified as commercial or residential. 
Table 6. Land-use/land-cover composition of monitored watersheds in Oakland County, Michigan, 1980 to 2000.

[All land-use/land-cover data in percent; refer to figure 4 for station locations]

\begin{tabular}{|c|c|c|c|c|c|c|c|c|c|c|c|}
\hline \multirow[b]{2}{*}{$\begin{array}{l}\text { Station } \\
\text { number }\end{array}$} & \multirow[b]{2}{*}{ Year } & \multirow[b]{2}{*}{ Built ${ }^{1}$} & \multirow[b]{2}{*}{ Residential } & \multirow[b]{2}{*}{ Commercial } & \multirow[b]{2}{*}{ Agricultural } & \multirow[b]{2}{*}{$\begin{array}{l}\text { Open } \\
\text { Space }\end{array}$} & \multirow[b]{2}{*}{ Forest } & \multirow[b]{2}{*}{ Water } & \multirow[b]{2}{*}{ Wetland } & \multicolumn{2}{|c|}{ Total } \\
\hline & & & & & & & & & & Built & Unbuilt \\
\hline \multirow{5}{*}{04166315} & 1980 & 5.3 & 35.5 & 7.5 & 6.7 & 25.9 & 11.2 & 0.4 & 7.5 & 48.2 & 51.8 \\
\hline & 1985 & 5.0 & 37.5 & 7.8 & 6.5 & 25.0 & 10.4 & 0.5 & 7.3 & 50.3 & 49.7 \\
\hline & 1990 & 4.2 & 50.5 & 9.9 & 4.6 & 15.9 & 8.2 & 0.5 & 6.3 & 64.5 & 35.5 \\
\hline & 1995 & 4.0 & 53.2 & 11.5 & 3.0 & 14.0 & 7.7 & 0.5 & 6.2 & 68.7 & 31.3 \\
\hline & 2000 & 5.4 & 61.2 & 13.2 & 0.8 & 7.5 & 5.2 & 0.5 & 6.2 & 79.8 & 20.2 \\
\hline \multirow{5}{*}{04170000} & 1980 & 4.2 & 20.6 & 3.1 & 12.7 & 24.3 & 12.0 & 7.8 & 15.4 & 27.8 & 72.2 \\
\hline & 1985 & 4.4 & 21.2 & 3.1 & 12.3 & 24.0 & 11.9 & 7.8 & 15.2 & 28.7 & 71.3 \\
\hline & 1990 & 4.3 & 26.6 & 3.7 & 10.8 & 20.4 & 11.0 & 8.0 & 15.0 & 34.7 & 65.3 \\
\hline & 1995 & 4.7 & 29.4 & 4.2 & 9.5 & 18.8 & 10.4 & 8.1 & 14.9 & 38.3 & 61.7 \\
\hline & 2000 & 6.3 & 36.2 & 6.3 & 5.9 & 13.4 & 9.4 & 8.2 & 14.3 & 48.9 & 51.1 \\
\hline \multirow{5}{*}{04170500} & 1980 & 4.8 & 19.6 & 2.8 & 12.7 & 24.9 & 12.8 & 8.1 & 14.2 & 27.3 & 72.7 \\
\hline & 1985 & 5.0 & 20.2 & 2.9 & 12.4 & 24.6 & 12.7 & 8.3 & 14.0 & 28.1 & 71.9 \\
\hline & 1990 & 4.9 & 25.6 & 3.5 & 10.9 & 21.0 & 11.7 & 8.6 & 13.8 & 34.0 & 66.0 \\
\hline & 1995 & 5.3 & 28.5 & 3.9 & 9.6 & 19.3 & 11.1 & 8.6 & 13.7 & 37.7 & 62.3 \\
\hline & 2000 & 6.9 & 35.1 & 6.0 & 6.2 & 14.0 & 9.9 & 8.7 & 13.2 & 48.1 & 51.9 \\
\hline
\end{tabular}

${ }^{1}$ Undifferentiated urban land, not clearly identified as commercial or residential.

Population-density estimates by watershed are given in table 7. Three important results can be observed in these estimates. First, overall population density is increasing in every watershed, the simple result of more people living in the fixed watershed area. Second, the population density in residential land is decreasing in several watersheds. In other words, the amount of land classified as residential is expanding more rapidly than the population is expanding. Third, the increase in population and increase in residential land by decade can be used to generate an estimate of the average density of residential space constructed during the period. These densities are also decreasing in most watersheds. The key assumption of this estimate is that the population density of the existing residential space is unchanged. These results indicate a consistent trend towards lower-density development, particularly in watersheds where development has been recent.

Table 7. Estimated population densities in gaged watersheds in Oakland County, Michigan, 1980 to 2000.

[Refer to figure 4 for station locations]

\begin{tabular}{|c|c|c|c|c|c|}
\hline Station number & Year & Residential acres & $\begin{array}{c}\text { Residential } \\
\text { (square miles) }\end{array}$ & Estimated population & $\begin{array}{l}\text { Residential population density } \\
\text { (persons per acre) }\end{array}$ \\
\hline \multirow{3}{*}{04143830} & 1980 & 2,061 & 3.22 & 11,200 & 5.44 \\
\hline & 1990 & 2,815 & 4.40 & 12,500 & 4.44 \\
\hline & 2000 & 4,920 & 7.69 & 16,000 & 3.25 \\
\hline \multirow{3}{*}{04148035} & 1980 & 1,749 & 2.73 & 7,280 & 4.16 \\
\hline & 1990 & 2,310 & 3.61 & 8,570 & 3.71 \\
\hline & 2000 & 3,606 & 5.63 & 10,800 & 2.99 \\
\hline
\end{tabular}


Table 7. Estimated population densities in gaged watersheds in Oakland County, Michigan, 1980 to 2000.

[Refer to figure 4 for station locations]

\begin{tabular}{|c|c|c|c|c|c|}
\hline Station number & Year & Residential acres & $\begin{array}{c}\text { Residential } \\
\text { (square miles) }\end{array}$ & Estimated population & $\begin{array}{l}\text { Residential population density } \\
\text { (persons per acre) }\end{array}$ \\
\hline & 1980 & 1,488 & 2.33 & 11,000 & 7.39 \\
\hline \multirow[t]{3}{*}{04160800} & 1990 & 1,856 & 2.90 & 12,200 & 6.57 \\
\hline & 2000 & 2,746 & 4.29 & 18,033 & 6.57 \\
\hline & 1980 & 7,906 & 12.35 & 67,900 & 8.59 \\
\hline \multirow[t]{3}{*}{04160900} & 1990 & 9,187 & 14.35 & 72,200 & 7.86 \\
\hline & 2000 & 12,444 & 19.44 & 89,400 & 7.18 \\
\hline & 1980 & 14,264 & 22.29 & 174,000 & 12.20 \\
\hline \multirow[t]{3}{*}{04161000} & 1990 & 15,737 & 24.59 & 177,000 & 11.25 \\
\hline & 2000 & 19,736 & 30.84 & 195,000 & 9.88 \\
\hline & 1980 & 5,119 & 8.00 & 38,900 & 7.60 \\
\hline \multirow[t]{3}{*}{04161540} & 1990 & 7,141 & 11.16 & 49,200 & 6.89 \\
\hline & 2000 & 11,369 & 17.76 & 66,500 & 5.85 \\
\hline & 1980 & 955 & 1.49 & 3,720 & 3.89 \\
\hline \multirow[t]{3}{*}{04161580} & 1990 & 1,727 & 2.70 & 3,940 & 2.28 \\
\hline & 2000 & 2,179 & 3.40 & 4,980 & 2.29 \\
\hline & 1980 & 25,708 & 40.17 & 274,000 & 10.66 \\
\hline \multirow[t]{3}{*}{04161810} & 1990 & 31,452 & 49.14 & 297,000 & 9.44 \\
\hline & 2000 & 41,966 & 65.57 & 347,000 & 8.27 \\
\hline & 1980 & 7,689 & 12.01 & 71,500 & 9.30 \\
\hline \multirow[t]{3}{*}{04166000} & 1990 & 8,505 & 13.29 & 76,600 & 9.01 \\
\hline & 2000 & 9,266 & 14.48 & 82,400 & 8.89 \\
\hline & 1980 & 19,232 & 30.05 & 175,000 & 9.10 \\
\hline \multirow[t]{3}{*}{04166100} & 1990 & 20,637 & 32.24 & 188,000 & 9.11 \\
\hline & 2000 & 22,138 & 34.59 & 202,000 & 9.12 \\
\hline & 1980 & 2,369 & 3.70 & 31,500 & 13.30 \\
\hline \multirow[t]{3}{*}{04166200} & 1990 & 2,397 & 3.74 & 31,500 & 13.14 \\
\hline & 2000 & 2,420 & 3.78 & 32,400 & 13.39 \\
\hline & 1980 & 2,078 & 3.25 & 20,100 & 9.67 \\
\hline \multirow[t]{3}{*}{04166300} & 1990 & 3,145 & 4.91 & 32,200 & 10.24 \\
\hline & 2000 & 3,876 & 6.06 & 41,600 & 10.73 \\
\hline & 1980 & 2,587 & 4.04 & 27,500 & 10.63 \\
\hline \multirow[t]{3}{*}{04166315} & 1990 & 3,667 & 5.73 & 39,500 & 10.77 \\
\hline & 2000 & 4,438 & 6.93 & 49,800 & 11.22 \\
\hline & 1980 & 10,425 & 16.29 & 76,143 & 7.30 \\
\hline \multirow[t]{3}{*}{04170000} & 1990 & 13,527 & 21.14 & 83,900 & 6.20 \\
\hline & 2000 & 18,255 & 28.52 & 103,000 & 5.64 \\
\hline & 1980 & 11,122 & 17.38 & 78,440 & 7.05 \\
\hline \multirow[t]{2}{*}{04170500} & 1990 & 14,537 & 22.71 & 86,600 & 5.96 \\
\hline & 2000 & 19,786 & 30.92 & 107,000 & 5.41 \\
\hline
\end{tabular}


The majority (55 percent) of land converted to urban uses was classified as open space in 1980, with forested and agricultural land accounting for an additional 42 percent (14 percent and 28 percent, respectively). Forest lands were nearly evenly divided between hardwoods and conifers (49 and 51 percent, respectively). The dominant agricultural use was cropland ( 85 percent of agricultural land), with small fractions classified as permanent pasture ( 8 percent) or livestock ( 4 percent).

\section{Correlation Between Land Cover and Streamflow Across the Urban Gradient}

In table 8, the Spearman rank-order correlation (p) coefficient and significance ( $\mathrm{p}$-value) for each correlation are listed. Residential and commercial land covers, as well as total percent built, watershed population density, and residential density all show significant positive correlations with high flows and flashiness but no significant correlations with low flows. Agricultural, open space, water, and wetland land covers show significant negative correlations with peak flows and flashiness but again, are not significantly correlated with low flows. The correlations with high flows and flashiness are well described in the literature; however, the absence of significant correlations with low flows may indicate that other factors, such as ground water pumping in rural areas or transfers of water into urban watersheds, are offsetting the anticipated decline in low flows as a result of decreased infiltration in urban areas.

Table 8. Spearman Rho values correlating specific characteristics of daily streamflow to land-cover and urbanization metrics across an urban gradient.

[Bold type indicates correlation significant at the 0.99 confidence level; --, correlation not significant at the 0.95 confidence level]

\begin{tabular}{lccc}
\hline & \multicolumn{3}{c}{ Exceedance flow } \\
Land use/land cover & $\mathbf{1 \%}$ & $\mathbf{9 9 \%}$ & Flashiness $^{1}$ \\
\hline Residential & $\mathbf{0 . 7 7}$ & -- & $\mathbf{0 . 7 8}$ \\
Commercial & 0.66 & -- & 0.69 \\
Agricultural & -0.60 & -- & -0.63 \\
Open Space & $\mathbf{- 0 . 7 3}$ & -- & $\mathbf{- 0 . 7 4}$ \\
Forest & -0.56 & -- & -0.64 \\
Water & -- & -- & -0.54 \\
Wetland & $\mathbf{- 0 . 8 4}$ & -- & $\mathbf{- 0 . 7 9}$ \\
Built percentage & $\mathbf{0 . 7 4}$ & -- & $\mathbf{0 . 7 6}$ \\
Overall population density & $\mathbf{0 . 7 7}$ & -- & $\mathbf{0 . 8 1}$ \\
Residential population density & 0.68 & -- & $\mathbf{0 . 7 4}$ \\
\hline
\end{tabular}

${ }^{1}$ Flashiness calculated as standard deviation of daily flow

\section{Correlation Between Land Cover and Water Quality Across the Urban Gradient}

Eight land-cover types and three measures of residential land-use intensity were compared to geometric means of water-quality characteristics measured at the 14 sample sites. Spearman rank-order correlation coefficients with p-values higher than 0.95 are listed in table 9 .

In general, the strongest correlations were with salt ions (sodium, potassium, and chloride). These ions were all strongly positively correlated with residential and commercial land covers, as well as overall percentage of the watershed built, population density, and residential population density. These ions were negatively correlated with agriculture, open space, forest, and wetland land covers. These correlations are also observed in the overall specific conductance, an indicator of salts in solution. Noncarbonate hardness, the combined concentration of calcium and magnesium ions that are in excess of the carbonate and bicarbonate ion concentration, also showed strong positive correlations with the development metrics and negative correlations with agriculture, open space, forest, and wetland land covers. These correlations may suggest some base leaching from soils in urbanized areas, resulting from exposure of carbonate soils to elevated concentrations of sodium and potassium.

Few significant correlations were observed between any of the land-use classes and nutrients. A weak correlation was observed between total organic nitrogen plus total ammonia and both commercial land use (Rho $=0.61, \mathrm{p}<0.05)$ and residential population density $($ Rho $=0.61, \mathrm{p}<0.05)$. Dissolved ammonia did correlate strongly with residential population density $(\mathrm{Rho}=0.72$, $\mathrm{p}<0.01$ ).

E. coli concentrations were strongly correlated with all of the development metrics and strongly negatively correlated with agriculture, open space, forest, and wetlands.

\section{Changes in Streamflow and Water Quality Through Time}

Annual high flows, low flows, and variability in stream flow were analyzed for 14 watersheds with headwaters in Oakland County. Five watersheds showed significant trends in low flows, one watershed showed a significant trend in peak flows, and none showed a significant trend in variability over the 33-year period. Relatively little change was observed in water chemistry, although phosphorus and sulfate concentrations were generally lower and chloride concentrations were generally higher in the 2001-2003 sampling compared to the 1966-1970 sampling. 
Table 9. Spearman rank-order correlations between water-quality parameters and land-use/land-cover metrics.

[All Rho values shown are significant at the 0.95 confidence level. Rho values in bold type are significant at the 0.99 confidence level; --, Rho value not significant at the 0.95 confidence level; ${ }^{\circ} \mathrm{C}$, degrees Celsius]

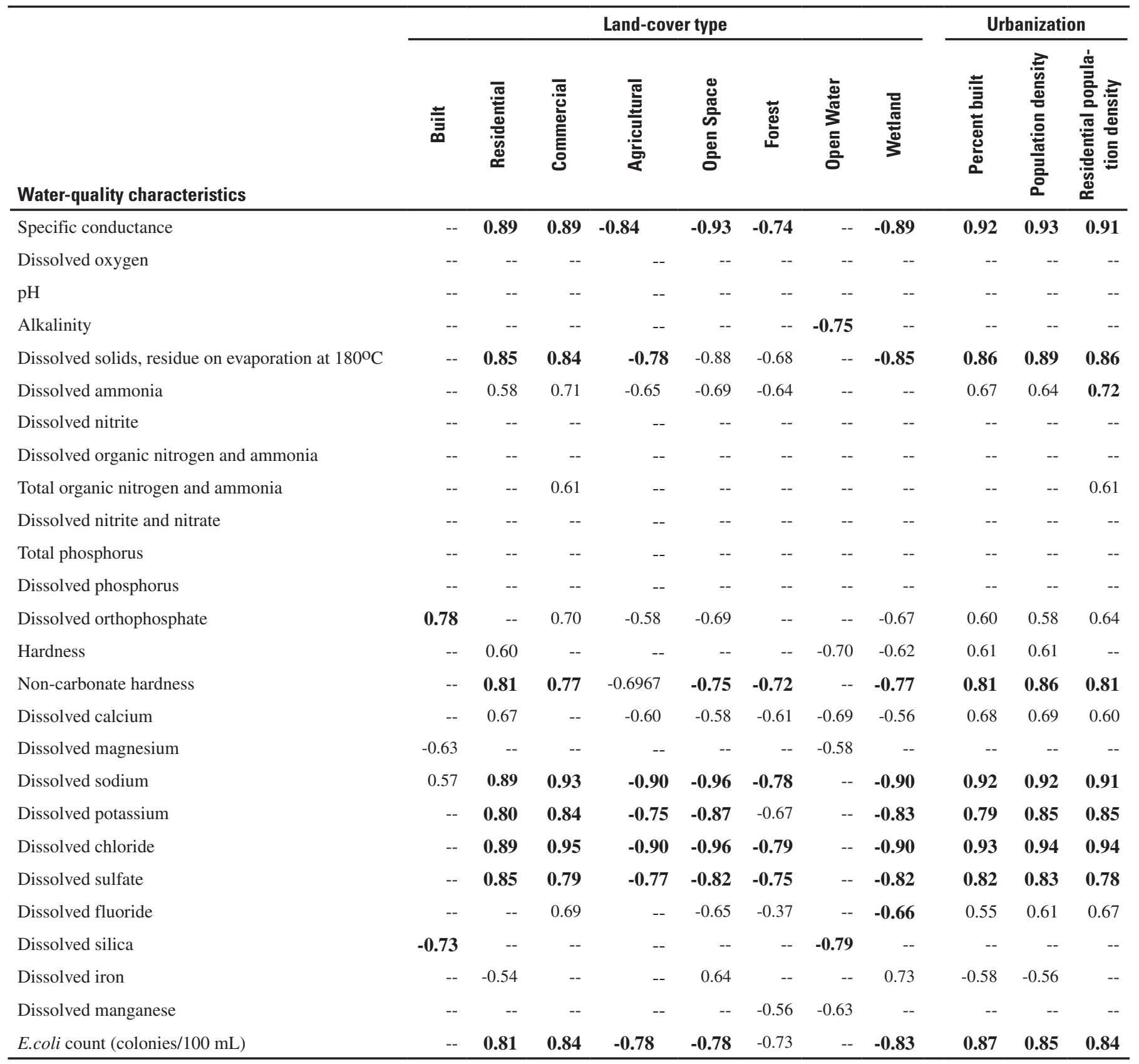

\section{Changes in Streamflow Characteristics}

Comparable land-cover data are not available prior to 1980 . Given the rates of land-cover change documented in table 6 between 1980 and 2000 and previous studies of the effect of land-cover change on streamflow, an increase in peak flows and flashiness, accompanied by a decrease in low flows, would be expected. How- ever, relatively little change was observed. The Spearman Rho values for each flow statistic at each streamflow-gaging station are shown in table 10.

Four watersheds showed statistically significant ( $\mathrm{p}$ $<0.10$ ) negative trends in the daily 99-percent-exceedance flow. These four watersheds are all moderately developed, and substantial portions of each meet their water needs from ground water. Observation wells at the 
Table 10. Spearman rank-order correlations between year and selected annual daily-streamflow statistics for water years 1970 through 2003.

\begin{tabular}{|c|c|c|c|c|c|c|}
\hline \multirow[b]{2}{*}{$\begin{array}{l}\text { Station } \\
\text { number }\end{array}$} & \multicolumn{2}{|c|}{$\begin{array}{l}\text { 99-percent } \\
\text { exceedance }\end{array}$} & \multicolumn{2}{|c|}{$\begin{array}{l}\text { Standard } \\
\text { deviation }\end{array}$} & \multicolumn{2}{|c|}{$\begin{array}{c}\text { 1-percent } \\
\text { exceedance }\end{array}$} \\
\hline & Rho & p-value & Rho & p-value & Rho & p-value \\
\hline 04143900 & 0.16 & 0.41 & 0.00 & 0.99 & -0.14 & 0.47 \\
\hline 04148140 & -0.33 & 0.06 & -0.13 & 0.47 & -0.15 & 0.39 \\
\hline 04160800 & -0.15 & 0.38 & -0.13 & 0.46 & -0.10 & 0.58 \\
\hline 04160900 & -0.55 & 0.02 & 0.09 & 0.60 & 0.06 & 0.74 \\
\hline $04161000^{1}$ & -- & -- & -- & -- & 0.49 & 0.02 \\
\hline 04161540 & -0.24 & 0.17 & -0.06 & 0.72 & 0.01 & 0.97 \\
\hline 04161580 & -0.21 & 0.24 & -0.26 & 0.14 & -0.29 & 0.09 \\
\hline 04164000 & -0.60 & 0.01 & -0.11 & 0.54 & 0.15 & 0.40 \\
\hline 04166000 & 0.50 & 0.00 & 0.29 & 0.10 & 0.31 & 0.08 \\
\hline 04166100 & 0.56 & 0.00 & 0.11 & 0.55 & 0.11 & 0.53 \\
\hline 04166200 & 0.18 & 0.30 & 0.14 & 0.39 & 0.10 & 0.57 \\
\hline 04166300 & -0.55 & 0.00 & 0.09 & 0.60 & 0.06 & 0.74 \\
\hline 04170000 & 0.05 & 0.77 & 0.00 & 0.99 & 0.08 & 0.64 \\
\hline
\end{tabular}

${ }^{1}$ Annual peak flows were used during the period this site was operated as a crest-stage gage

Commerce, White Lake, and Groveland Townships have all reported record depths to ground water during fall 2003 (Blumer and others, 2003). The absence of a corresponding increase in peak flows or variability suggests that this decrease in low flows is the result of increased ground-water demand rather than a shift from infiltration to runoff. Two watersheds in southern Oakland County showed statistically significant positive trends in this low-flow metric. These upward trends are likely the result of (1) municipalities shifting from ground water to surface water as a source of water supply, and (2) leakage from the delivery mains. These two watersheds are heavily developed and are supplied with approximately $125 \mathrm{Mgal} / \mathrm{d}$ of surface water from Lake Huron by the Detroit Water and Sewer Department (C.L. Luukkonen, U.S. Geological Survey written commun., 2004). Twenter and Knutilla (1972) documented more than 100 feet of drawdown in the Pontiac area during the 1960s as a result of pumping for public water supply. Although no current observation data are available for monitoring wells in the Pontiac area, an observation well at the Cranbrook Academy has recovered and actually began flowing at land surface since it was last monitored in the 1970s.
No watershed showed a statistically significant trend in the variability of daily flows. One watershed, the Clinton River at Auburn Hills (04161000), showed a significant positive trend in the 1-percent exceedanceflow, a measure of high flow. Although a clear trend exists in the 1-percent-exceedance flow data up to 1982, no significant difference exists between the 1-percentexceedance flows for 2001-2003 and the data collected prior to 1982.

\section{Changes in Stream-Water Quality Through Time}

Comparisons between the 1960s low-flow samples and low-flow samples collected in 2002 and 2003 are shown in figures $5 \mathrm{a}-\mathrm{f}$. The values for each time period were computed by calculating the geometric mean of the low-flow samples in each time period. For purposes of describing an increase or decrease, a difference of more than 10 percent of the concentration from the 1966-1970 mean is considered a change; a difference of less than 10 percent is considered no change. Specific conductance increased at 12 of 13 sites for which prior data are available, but it remained unchanged at one site (04143830). Concentrations of chloride increased at every site, and more than doubled at 11 of the 13 sites for which prior data are available.

Concentrations of phosphorus decreased at seven of the nine sites for which prior data were available but increased at the two remaining sites (04148035 and 04166315). Concentrations of sulfate decreased at 8 of 13 sites for which prior data were available while remaining unchanged at 5. Data from the National Atmospheric Deposition Network (2004) indicate that atmospheric deposition of sulfur has decreased dramatically over the past 20 years in the Upper Midwest. The two sites where sulfate concentrations are unchanged are on the Huron River downstream from the City of Milford Wastewater Treatment Plant. Nitrate concentrations increased at 5 of 12 sites for which data are available while decreasing at 5 and remaining unchanged at 2 . Nitrate concentrations more than doubled at three sites, 04161000, 04161810, and 04166315. Noncarbonate hardness increased at 9 of 14 sites, was unchanged at 3 sites, and decreased at 2 sites.

Increased chloride concentrations, and accompanying increases in specific conductance, are an anticipated effect of urbanization. The decreases in nutrients and sulfate concentrations, combined with little change in the streamflow characteristics, contradict the expected effects of urbanization based on the literature. 


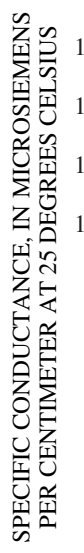

(a.)

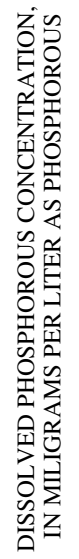

(c.)

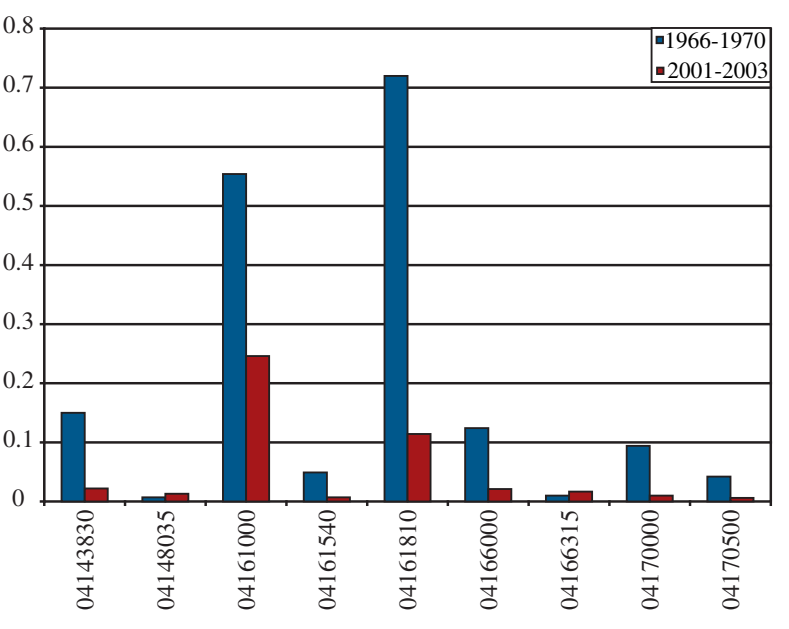

STATION NUMBER

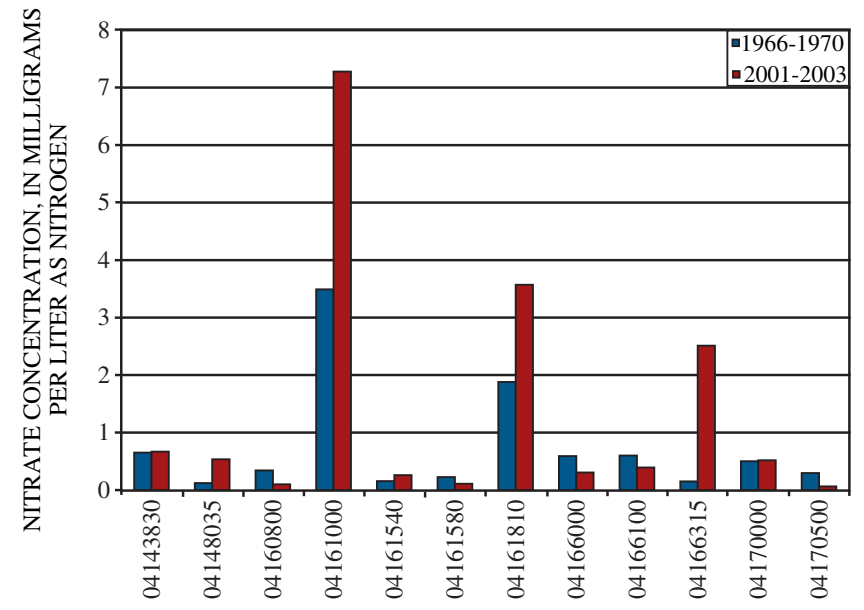

(e.)

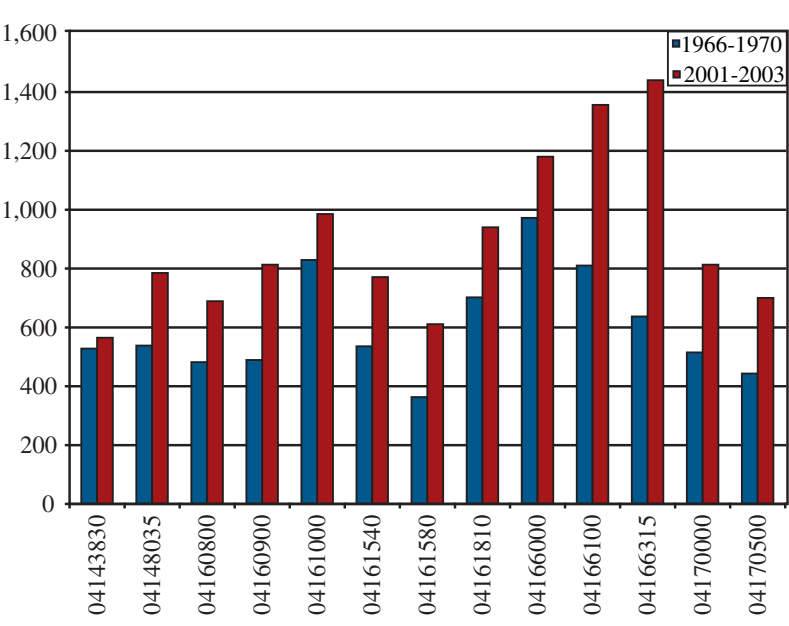

STATION NUMBER (b.)

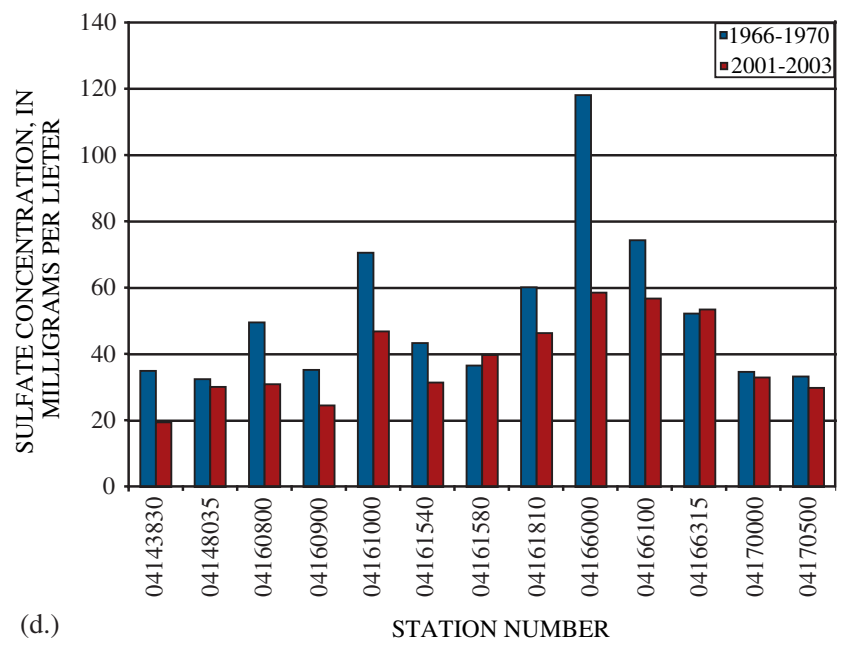

Figure 5. Comparison of geometric mean (a.) specific conductance, (b.) chloride concentration, (c.)phosphorous concentration, (d.) sulfate concentration, (e.) nitrate concentration, and (f.) noncarbonated hardness of discrete water-quality samples collected during low flow conditions, 1966-1970 and 2001-2003.

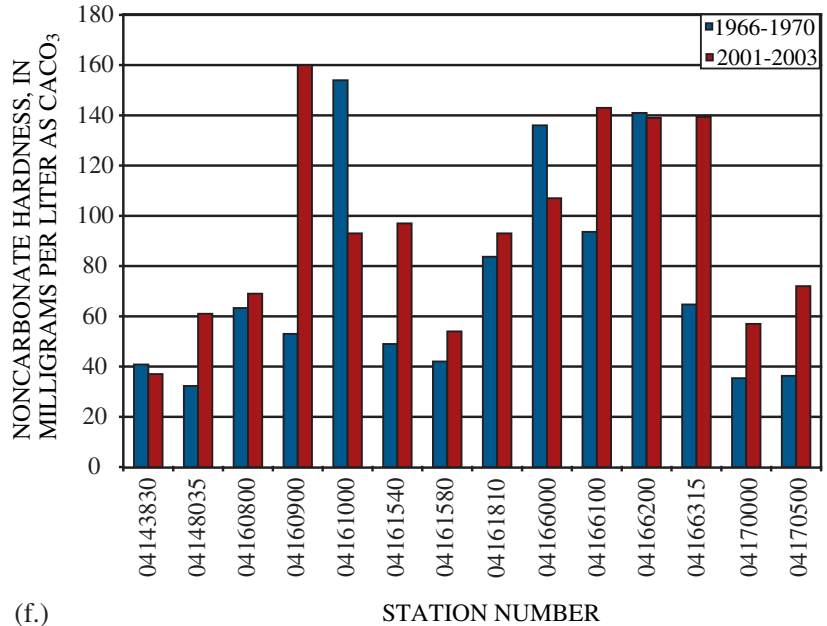




\section{Summary and Conclusions}

The U.S. Geological Survey, in cooperation with Oakland County, Mich., evaluated streamflow and waterquality records for 14 watersheds in Oakland County, Michigan, using temporal and urban gradient analysis methods to identify effects of land-use change on streamflow and water-quality characteristics from 1970 to 2003. Each type of analysis method uses a different type of data and is sensitive to different effects. Available land-cover and population data were standardized to be consistent through time, and dasymetric mapping was used to distribute population data (collected at the minor civil division level) to watershed boundaries. These standardized land cover and population datasets were used to quantify change in land-cover and population across the 14 watersheds studied. The effects of landcover change on hydrologic systems, particularly the effects on streamflow characteristics and water quality, is a concern in Michigan and across the United States.

Clear, monotonic, and substantial increases in urban land covers have taken place in every one of the 14 study watersheds. In some cases, these increases represent conversion of more than 25 percent of the total watershed area to urban use from1980-2000. Analysis of these urbanization patterns indicates that although population density and urban land covers in already urbanized areas are increasing, urban land covers are increasing more rapidly in less-developed areas. In these lessdeveloped areas, the trend is also consistently towards lower-density residential space.

On the basis of previous studies, several changes in streamflow and water quality would be expected. First, an increase in high flows would be expected. This change was observed in only one of the 14 watersheds, but the flow-measurement site was inactive for a substantial period, which may affect the result. The daily streamflow data used in the time-series analysis are less sensitive to changes in high flows than instantaneous streamflow data are, and this may account for the lack of an observable trend; however, changes in development practices during the period from 1970-2003, particularly the trend to larger residential lots and requirements for storm-water management, may have damped the effects of urbanization on high flows.

Second, a decrease in low flows would be expected. This change was observed in 3 of the 14 watersheds (at streamflow-gaging stations 04148140, 04160900, 04166300). Ground-water levels were measured in two of these watersheds, and new period-of-record lows were recorded during summer 2003. In 2 of the 14 watersheds (at stations 04166000 and 04166100 ) significant positive trends in low flows were found. These two watersheds are heavily developed and supplied with surface water from the Detroit Water and Sewerage Department
(DWSD) at a rate of approximately $125 \mathrm{Mgal} / \mathrm{d}$. Leakage from both the supply and removal systems likely contributes water to streamflow. Ground water has ceased to be a significant source of water supply in these watersheds. The combination of leakage from the DWSD system and the gradual recovery of the local ground-water system following the cessation of pumping in the 1960s likely explains the positive trend in low flows in these two watersheds.

Third, increased urbanization, including increased amount of impervious surface, would be expected to result in increased variability in streamflows, commonly referred to as flashiness. None of the 14 watersheds studied showed any significant trend in daily streamflow variability over the 33-year period studied. As discussed previously, daily data are not as sensitive to change as instantaneous data. Changes in development practices from 1970-2003, particularly the trend to larger residential lots and requirements for stormwater management, may have damped the effects of urbanization on variability.

Anticipated changes in water quality included increases in most measured characteristics, including dissolved solids, specific conductance, chloride, nitrogen, phosphorus, and sulfate. Only total dissolved solids and chloride concentrations increased at all sites. Sulfate and phosphorus concentrations decreased at most sites, although the decreased concentrations of sulfate are most likely due to decreased atmospheric deposition. Nitrate concentrations were largely unchanged.

The gradient analysis showed similar results with regard to water-quality characteristics. Although relatively few correlations existed between any land cover and nutrients, urban land covers and measures of urbanization were all highly positively correlated with specific conductance, dissolved solids, noncarbonate hardness, sodium, potassium, chloride, sulfate, and number of $E$. coli bacteria. With regard to streamflow characteristics, the gradient analysis showed highly significant positive correlations between the urban land covers and high flows as well as variability, but no significant correlation with low flows.

Although the effects of cumulative urbanization can be clearly correlated with increased peak flows and variability as well as increases in concentrations of salts, sulfate, phosphorus, nitrogen, and E. coli, within the framework of an urban gradient, the data collected in the last several decades show relatively few of these changes, with the exception of the increase in salts.

The data sets available for both temporal and gradient analyses are limited in several ways. Whereas temporal methods enable one to evaluate incremental effects through time but are limited by the relatively lower quality hydrologic data available, gradient analysis only measures the cumulative effect of changes throughout 
time including potentially different regulatory and design environments. Given the data available, relatively few of the anticipated changes in streamflow and water quality associated with land-cover change are observable from 1970-2003. Although the absence of these changes may be the result of increased stormwater management requirements and changes in development patterns, it is also possible that the changes are not detectable with the data available. The gradient analysis identifies most of the anticipated effects of land-cover change but does not differentiate when the change occurred.

In next decade, sufficient periods of record for land-cover, streamflow, and water-quality data should be available to allow more comprehensive temporal analysis of the higher-quality hydrologic data over an incremental timeframe.

\section{Acknowledgments}

The author thanks Ann Burns and Lisa Mayoras, both with the Southeast Michigan Council of Governments, for making available population and land-cover data, respectively. The author also appreciates the assistance, comments, and recommendations of Dr. Thomas J. Gordon and the staff of the Oakland County Department of Human Services.

\section{References Cited}

Aichele, S.S., Crowley, S.L., Taricska, C.J., Stopar, J., Water Resources Data, Oakland County, Michigan 2001-2004. U.S. Geological Survey Open-File Report 2004-1417, 75 p.

Anderson, J.R., Hardy, E.E., Roach, J.T., and Witmer, R.E., 1976, A land-use and land-cover classification system for use with remote sensor data: U.S. Geological Survey Professional Paper 964, 27 p.

Blumer, S.P., Behrendt, T.E., Whited, C.R., Ellis, J.M., Minnerick, R.J., and LeuVoy, R.L., Water resources data, Michigan, Water Year 2003: U.S. Geological Survey Water-Data Report MI-03-1, 499 p.

Choi, J. Y., Engel, B.A., Muthukrishnan, S., and Harbor, J., 2003, GIS-based long-term hydrologic impact evaluation for watershed urbanization: Journal of the American Water Resources Association, v. 39, no. 3, p. 623-635.

Ebdon, D., 1992, Statistics in geography ( 2nd ed.), Cambridge, Mass., Blackwell Publishers, 230 p.
Eicher, C.L., and Brewer, C.A., 2001, Dasymetric mapping and areal interpolation-implementation and evaluation: Cartography and Geographic Information Science, v. 28, p. 125-138.

Fishman, M.J., 1993, Methods of analysis of the U.S. Geological Survey National Water Quality Laboratory - Determination of inorganic and organic constituents in water and fluvial sediments: U.S. Geological Survey Open-File Report 93-125, $273 \mathrm{p}$.

Fishman, M.J., and Friedman, L.C., 1989, Methods for determination of inorganic substances in water and fluvial sediments: U.S. Geological Survey Techniques of Water Resources Investigations, book 5, chap. A1, 454 p.

Frenzel, S.A., and Couvillion, C.S., 2002, Fecal-indicator bacteria in streams along a gradient of residential development: Journal of the American Water Resources Association, v. 38 , no. 1, p. 265-274.

Garreau, J., 1992, Edge City - Life on the new frontier: Anchor, New York, 576 p.

Harris, E.E., and Rantz, S.E., 1964, Effect of urban growth on streamflow regimen of Permanente Creek, Santa Clara, California: U.S. Geological Survey Water-Supply Paper 1591-B, 17 p.

Im, S., Brannan, K.M., and Mostaghimi, S., 2003, Simulating hydrologic and water-quality impacts in an urbanizing watershed: Journal of the American Water Resources Association, v. 39, no. 6, p. 1465-1479.

Kalnai, E., and Cal, M., 2003, Impact of urbanization and land-use change on climate: Nature, v. 423, p. 528-531.

Kendall, M.G., 1955, Rank correlation methods (5th ed): London, Charles Griffin and Company, Ltd., 196 p.

Leopold, L.B., 1968, Hydrology for urban land planning — A guidebook on the hydrologic effects of urban land use: U.S. Geological Survey Circular 554, 17 p.

Malmqvist, B., and Rundle, S., 2002. Threats to the running water ecosystems of the world: Environmental Conservation v. 29 , no. 2 , p. $134-153$.

Martens, L.A., 1968, Flood inundation and effects of urbanization in metropolitan Charlotte North Carolina: U.S. Geological Survey Water-Supply Paper 1591-C, 60 p.

McMahon, G., Bales, J.D., Coles, J.F., Giddings, E.M.P., and Zappia, H., 2003, Use of stage data to characterize hydrologic conditions in an urbanizing environment: Journal of the American Water Resources Association, v. 39, p. 15291546. 
McMahon, G. and Cuffney, T.F., 2000, Quantifying urban intensity in drainage basins for assessing stream ecological conditions: Journal of the American Water Resources Association, v. 36, p. 1247-1261.

Mennis, J., 2003, Generating surface models of population using dasymetric mapping: The Professional Geographer, v. 55 , p. 31-42.

Michigan Center for Geographic Information, 2002, Michigan geographic data library, accessed January 20, 2004, at http:// www.mcgi.state.mi.us/mgdl

Michigan Land Use Leadership Council, 2003, Michigan's Land, Michigan's Future - Final Report of the Michigan Land Use Leadership Council: Michigan Land Use Leadership Council, Lansing, Michigan, 90 p.

Monmonier, M.S., and Schnell, G.A., 1984, Land-use and land-cover data and the mapping of population density: International Yearbook of Cartography, v. 24, p. 115-121.

Myers, D.N., and Sylvester, M.D., 1997. National Field Manual for the collection of water-quality data - Biological indicators: U.S. Geological Survey Techniques of WaterResources Investigations, book 9, chap. A7, 38 p.

National Atmospheric Deposition Program, 2004, National trends network, accessed February 9, 2004 at http://nadp. sws.uiuc.edu/sites/ntnmap.asp?

Openshaw, Stan, 1983. The modifiable areal unit problem: Norwick, U.K., GeoBooks, Concepts and Techniques in Modern Geography, no. 38, 41 p.

Owe, Manfred, 1985, Long-term streamflow observations in relation to basin development: Journal of Hydrology, v.78, p. 243-260.

Patton, C.J., and Truitt, E.P., Methods of analysis of the U.S. Geological Survey National Water Quality Laboratory - Determination of total phosphorus by a Kjeldahl digestion method and an automated colorometric finish that includes dialysis: U.S. Geological Survey Open-File Report 92-146, $39 \mathrm{p}$.

Richter, B.D., Baumgartner, J.V., Powell, J., and Braun, D.P., 1996, A method for assessing hydrologic alteration within ecosystems: Conservation Biology, v. 10, no. 4, p. 11631174.

Savini, J., and Kammerer, J.C., 1961, Urban growth and the water regimen: U.S. Geological Survey Water-Supply Paper 1591-A, 42 p.
Shelton, L.R., 1994, Field guide for collecting and processing stream water samples for the National Water Quality Assessment Program: U.S. Geological Survey Open-File Report 94-455, 42 p.

Smith, J.H., Wickham, J.D., Norton, D., Wade, T.G., and Jones, K.B., 2001, Utilization of landscape indicators to model potential pathogen impaired waters. Journal of the American Water Resources Association, vol. 37, no. 4, p. 805-814.

Smyth, A.H., (ed.), 1907, The writings of Benjamin Franklin, v. 9, New York, Macmillan, Co.

Tobler, W., 1979, Smooth pycnophylactic interpolation for geographic regions: Journal of the American Statistical Association, v. 74, p. 519-530.

Tufford, D.L., Samarghitan, C.L., McKellar, H.N., Porter, D.E., Hussey, J.R., 2003, Impacts of urbanization on nutrient concentrations in small southeastern coastal streams: Journal of the American Water Resources Association, v. 39, no. 2, p. 301-312.

Turner, M.G., O’Neill, R.V., Gardner, R.H., and Milne, B.T., 1989, Effects of changing spatial scale on the analysis of landscape pattern: Landscape Ecology, v. 3, p. 153-162.

Twenter, F.R., and Knutilla, R.L., 1972, Water for a rapidly growing community - Oakland County, Michigan: U.S. Geological Survey Water-Supply Paper 2000, 140 p.

U.S. Environmental Protection Agency, 1994, Methods for the determination of inorganic substances in environmental samples: Available from National Technical Information Service as PB94-120821, 169 p.

U.S. Geological Survey, 2003, User's manual for the national water information system of the U.S. Geological Survey: U.S. Geological Survey Open-File Report 03-123, 407 p.

Vice, R.B., Guy, H.P., and Ferguson, G.E., 1969, Sediment movement tin an area of suburban highway construction, Scott Run Basin, Fairfax County, Virginia, 1961-1964: U.S. Geological Survey Water-Supply Paper 1591-E, 41 p.

Wilde, F.D., and Radtke, D.B., 1998, Field measurements - National field manual for the collection of water-quality data: U.S. Geological Survey Techniques of WaterResources Investigations, book 9, chap. A6, 246 p.

Wright, J.K., 1936, A method of mapping densities of population with Cape Cod as an example: Geographical Review, v. 26, p.103-110. 
